\begin{abstract}
ALKOR -Berichte
Bachelor-MARSYS education cruise in the Baltic Sea
\end{abstract}

Cruise No. AL539

\author{
05.07. - 18.07.2020, \\ Kiel (Germany) - Warnemünde (Germany) \\ BALTEACH - 1
}

Richard Klinger, Elisa Schaum, Jens-Peter Herrmann

Richard Klinger
Institute for Marine Ecosystem and Fishery Science 
Table of Contents

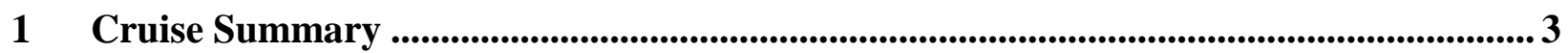

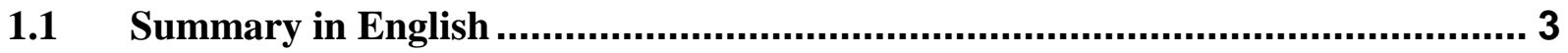

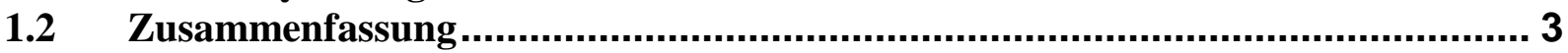

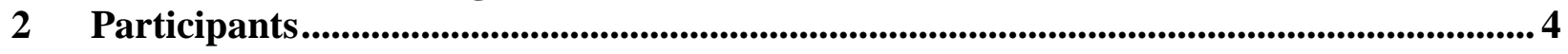

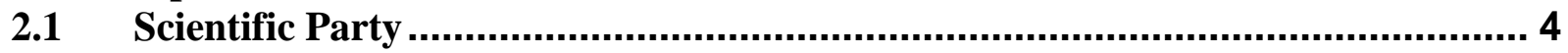

$2.2 \quad$ Participating Institutions .............................................................................. 4

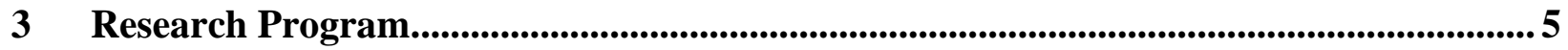

3.1 Aims of the Cruise .................................................................................................. 5

3.2 Agenda of the Cruise ................................................................................. 5

3.3 Description of the Working Area ................................................................ 7

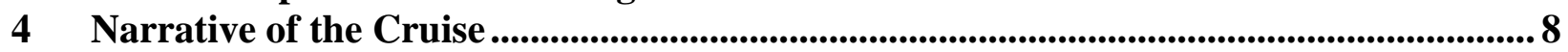

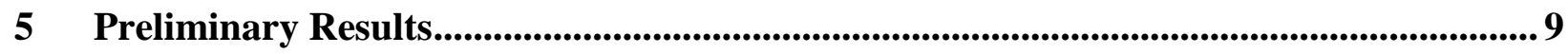

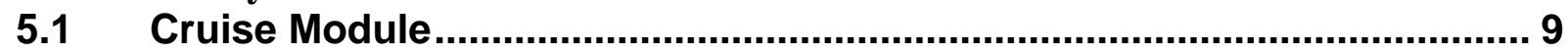

5.2 Phytoplankton sampling ...................................................................... 11

5.2 Ichthyo- and zooplankton sampling ................................................ 13

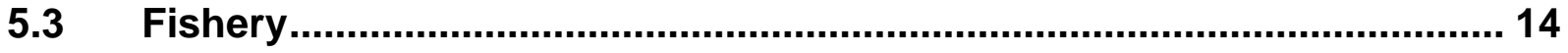

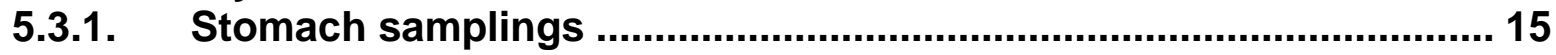

5.3.2. Single fish cod sampling ............................................................... 16

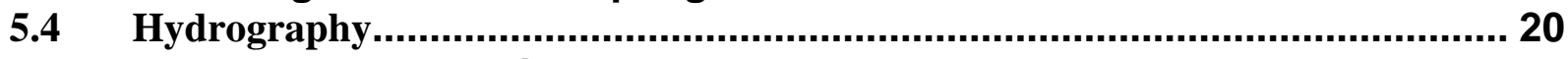

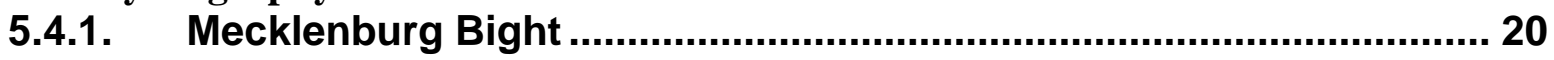

5.4.2. Bornholm Basin.............................................................................. 21

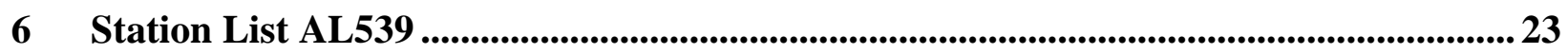

6.1 Overall Station List ................................................................................. 23

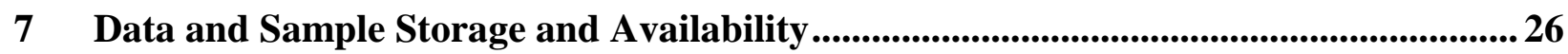

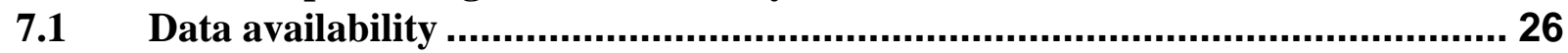

7.2 Sample availability and storage .......................................................... 26

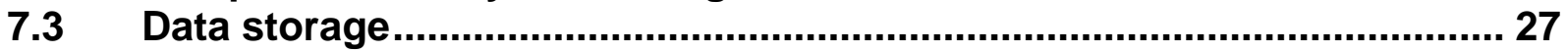

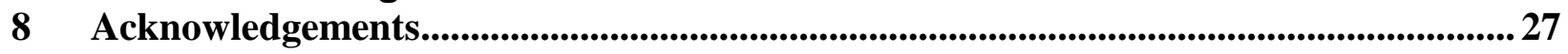

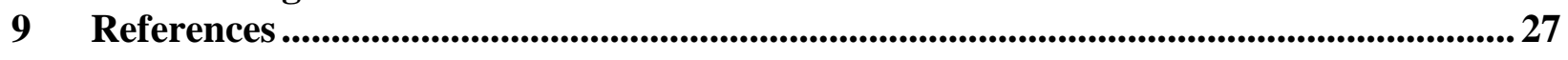

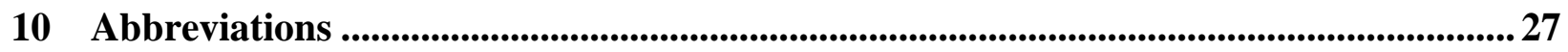




\section{Cruise Summary}

\subsection{Summary in English}

During this teaching cruise, bachelor students of the Institute of Marine Ecosystem and Fishery Science (IMF) were supposed to get the opportunity to learn about the most commonly used scientific methods, gears and working procedures on board of a research vessel for fisheries science as well as biological oceanography.

Due to regulations which were applied to the ongoing corona pandemic, students were unfortunately not allowed to attend, resulting in a reduction of scientific crew participations to 6 IMF employees.

Therefore, a teaching module was created in order to reach the educational goals of the cruise, which conveys knowledge to the students in a digital format, during lectures, explanatory video material and by working with collected data from the present and past cruises.

The scientific objective of the cruise was the investigation of distribution patterns of certain spawning fish species, such as cod, whiting, sprat, plaice, flounder and dab in the Kiel, Arkona and with special focus within the Bornholm Basin.

In addition to fisheries, a comprehensive grid of plankton net stations was sampled in order to gain insights into the spatial distribution of fish eggs, planktivorous prey (larval to adult life stages) cod larvae and plankton distribution (most important for sprat) within the Bornholm Basin.

Of special interest were picoplankton communities' short term responses (on board) to temperature along the respective gradient in the Baltic Sea with an additional sampling scheme to later isolate Ostreococcus sp. and its associated viruses for future laboratory studies at the Institute for Marine Ecosystem and Fishery Science.

\subsection{Zusammenfassung}

Auf dieser Lehrausfahrt sollte Bachelor- und Master-Studierenden des Instituts für Marine Ökosystem- und Fischereiwissenschaften (IMF) die Möglichkeit gegeben werden, die am häufigsten verwendeten wissenschaftlichen Methoden, Geräte und Arbeitsverfahren der Fischereiwissenschaft sowie der biologischen Ozeanographie an Bord eines Forschungsschiffes kennenzulernen.

Aufgrund der andauernden Corona-Pandemie mussten Regeln eingehalten werden, welche es den Studierenden leider nicht erlaubte an der Reise teilzunehmen. Außerdem musste die wissenschaftliche Besatzung auf 6 Mitarbeiter des IMF reduziert werden.

Um jedoch trotzdem die Ausbildungsziele der Studierenden zu erreichen, wurde ein Lehrmodul kreiert, welches das Vermitteln von Lehrinhalten auf digitalen Wegen beinhaltete, bestehend aus Vorlesungen, Lehrvideos und wissenschaftlicher Arbeit mit gewonnen Daten der aktuellen und vergangener Seereisen.

Wissenschaftliches Ziel dieser Reise war die Untersuchung der Verteilungsmuster bestimmter laichender Fischarten wie dem Dorsch, Wittling, Sprotte, Scholle, Flunder und Kliesche in der Kieler Bucht, im Arkona und mit besonderem Fokus innerhalb des Bornholm Beckens.

Neben der Fischerei wurde ein umfassendes Grid aus Planktonstationen beprobt, um Einblicke in die räumliche Verteilung von planktischen Beutearten (Larven bis zu adult Stadien), Fischeiern, Dorsch-Larven und Planktonverteilungen im Bornholm Becken gewinnen.

Von besonderem Interesse waren die Kurzzeitreaktionen von Picoplankton-Gemeinschaften (an Bord) auf Temperatur entlang des jeweiligen Gradienten in der Ostsee mit einem zusätzlichen Probenahmeschema zur späteren Isolierung von Ostreococcus sp. und den assoziierten Viren, für zukünftige Laboruntersuchungen am Institut für Marine Ökosystem- und Fischereiwissenschaften. 


\section{Participants}

\subsection{Scientific Party}

\begin{tabular}{lll}
\hline Name & Discipline & Institution \\
\hline Klinger, Richard & Chief scientist; PhD student & IMF \\
Listmann, Luisa & PostDoc & IMF \\
Nowicki, Margarethe & PhD student & IMF \\
Funk, Steffen & PostDoc & IMF \\
Plonus, Rene & PhD student & IMF \\
Hornetz, Peter & Scientific Assistant; MSc student & IMF \\
\hline
\end{tabular}

\subsection{Participating Institutions}

IMF Institute of Marine Ecosystem and Fishery Science, University of Hamburg 
Research Program

\subsection{Aims of the Cruise}

This cruise was planned as a teaching cruise for MARSYS Bachelor students from the Institute of Marine Ecosystems and Fisheries Science (IMF, University of Hamburg), aiming to train students in different sampling methods of marine ecology and fishery science.

The key characteristic is the integration of oceanographic and biological information to enhance understanding of the spatial distribution of pelagic fish eggs and larvae, phytoplankton and zooplankton abundance patterns as well as fish abundances in dependence of climate change and anthropogenic stressors.

The cruise is designed to train students in sampling methods targeting the different compartments of a marine ecosystem. The methods cover CTD profiles, phyto- and zooplankton samples as well as fishing operations. All students were supposed to be trained in all technical procedures including work on deck, sample preparation and conservation, labelling documentation and storage. Students should have also received training in pre-analyzing samples and species identification on species based taxonomic level to get an overview of the biodiversity of the system.

Due to the ongoing process of Covid-19 infections, a variety of rules had to be followed. This led to the following: One, the scientific cruise members allowed to attend the cruise was reduced to 6 people, in order to maintain a usage of the accommodation chambers by a single person. Two, students were not allowed to attend the cruise, due to regulations by the University of Hamburg, which prohibited the participation during excursions and field work.

In order to reach the attended goal, an online teaching module was brought to life, aiming at a widely diverse education regarding preparation, conduction and post processing of a scientific cruise.

For further descriptions of the module (initiated and coordinated by Dr. Luisa Listmann) please see 5.1 Cruise Module

\subsection{Agenda of the Cruise}

The cruise had three main objectives with regard to the scientific training of our students:

1. Provide knowledge and practical skills with regard to the operation of a broad range of different gears needed to sample and investigate the different ecological compartments of a marine ecosystem covering ocean physics, chemistry, plankton, and fish.

2. Provide insights and experiences regarding cruise organization and sampling strategies, producing meaningful estimates of abundance, biomass in relation to a stratified marine ecosystem.

3. Provide opportunities to gather relevant data and specimens for bachelor, master and $\mathrm{PhD}$ theses.

This cruise program is designed to introduce students of the institute to a scientifically sound practice of standard working procedures on board. As a basis of the teaching procedure, the daily work plan includes a concept of rotation through a range of different subjects. Four different fields of responsibility are defined, in which each student receives individual training, or in a group of 2, to theoretically establish practical knowledge of work on a research vessel. Individual training would have entailed the introduction of each student each individual topic with the goal to handle everything at a certain point by themselves. Therefore, experienced staff members of the institute lead the teaching process and give guidance throughout the entire process, resulting in gapless mentoring. This year, the online teaching module was created using 
digital methods such as videotaping and audio recording on board in order to achieve the aforementioned teaching goals.

Theoretically, the students are lead through the following fields of responsibilities:

I. Gear:

Deploying gears, including the handling of the: voice intercom system, gear software, data documentation and station work coordination. During fishing, for example advanced students would have been on the bridge to get some insights on how hydroacoustic methods are used for fishery science.

II. Working deck:

Practical work on deck, including: preparing the variety of gears for their use; supporting the crew to maneuver the gear in and out of the water.

III. Sampling:

Handle the plankton samples correct until they are labelled, fixed and stored properly. Processing of fish hauls with the trawls, including: coordination of the working procedures as taking adequate subsamples, fish sorting and species identification, lengthfrequency measurements and determination of sex, maturity as well as otolith preparation, for age determination. These steps add up to apply basic and advanced methods needed for assessment of fish populations.

IV. Lab.coordination:

Including: on one hand the in-situ measurement of, for example phytoplankton samples as well as sorting and determination of fish larvae. On the other hand, the students learn the organization of all work procedures in the laboratory, as preparing laboratory utilities, protocol management, cleanliness and accomplish general jobs that keep the work flow organized and efficient.

This scheme was digitally implemented into the module, by the creation of explanatory videos, aiming at the different topics. 
The spatial focus during this cruise has been the Mecklenburg Bight and especially the Bornholm Basin, a variety of samplings were also conducted within the Kiel Bight, see Figure 3.1. Due to unfavorable weather conditions, the planned work schedule had to be changed on a daily basis, therefore some stations and investigations which were planned for the following cruise AL540 had to be preponed, resulting in a shift of AL539 investigations to the latter cruise. The training includes collecting samples from all major compartments of the ecosystem, from coastal to open waters in a 3-dimensional distribution. To get a holistic understanding, students should have learned how to take, prepare and pre-analyze samples on board as well as postcruise-processing of collected data or samples in the laboratory. Mentioned aspects were realized by a variety of explanatory videos, as part of the created cruise module, listed within 5.1 Cruise Module.

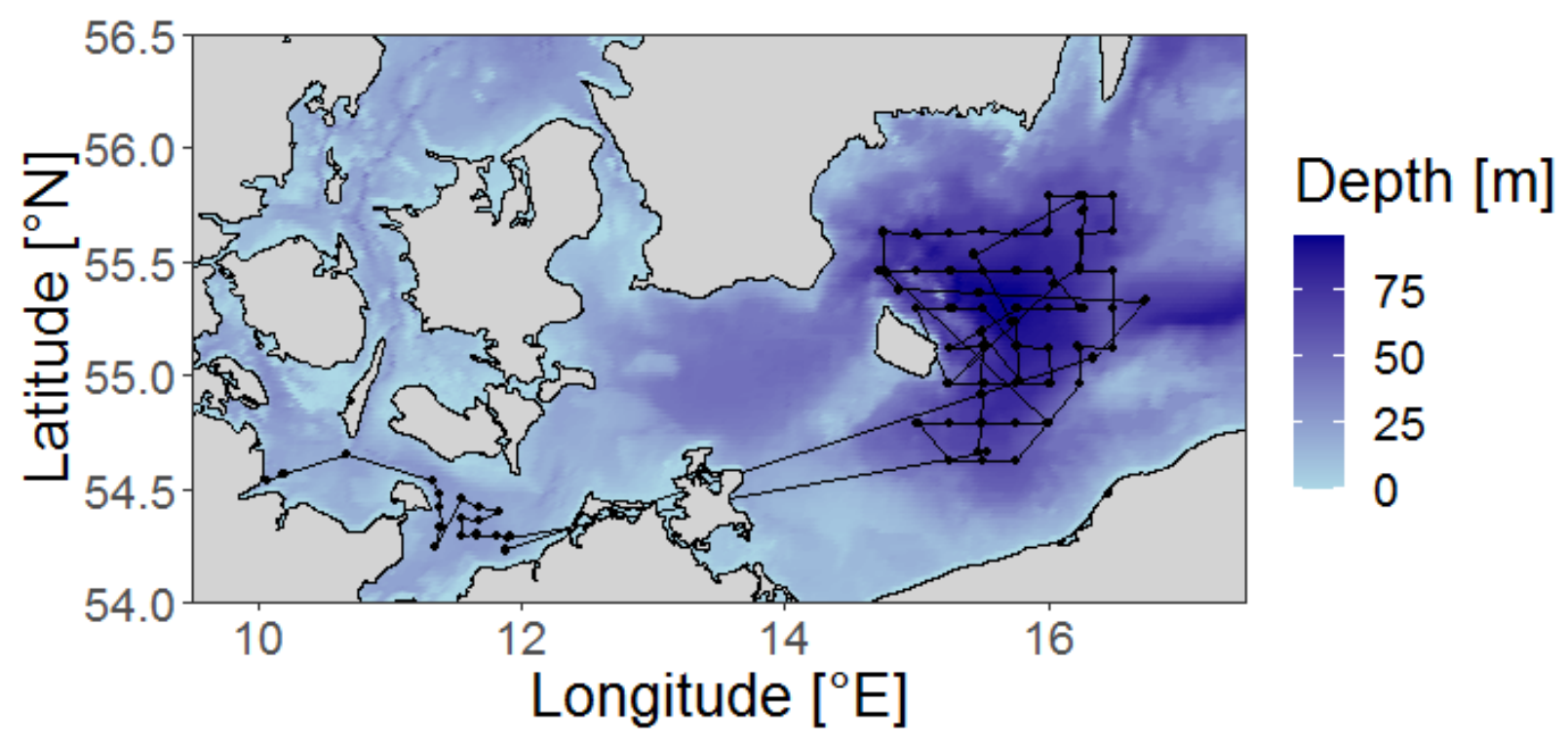

Figure 3.1: Cruise track of AL539. All realized sample stations are depicted by black dots. Positions per Gear are given in Table 6.1.

Specific investigations included a detailed hydrographic survey (oxygen, salinity, temperature, light intensity, fluorescence), plankton surveys (phyto-, zoo- and ichthyoplankton, with the goal to determine the composition, abundance, vertical and horizontal distribution) and fishery hauls.

The latter served to, firstly, determine size distributions, maturity status, and length - weight relationships of the three dominant fish species within the ecosystem Baltic Sea, cod (Gadus morhua), herring (Clupea harengus) and sprat (Sprattus sprattus). Secondly, various different samples were obtained for more detailed analyses, stomachs of cod, herring and sprat; otoliths of cod for the determination of the individual age. In addition, along the cruise track, hydroacoustic (echosounder) data were collected continuously for later analysis of fish abundance and distribution. 
Since most of the samples are "dual use" in the sense that they are also either used for thesis work or in national (Senckenberg Research Institute, German Center for Marine Biodiversity Research) and international teaching cooperations (DTU Aqua), the students are also highly encouraged to work carefully and responsibly.

Further, the grid stations provide an opportunity to study variability and patchiness but also allow us to investigate the effects of influencing factors such as depth and hydrography. Our Phyto-Plankton group uses these cruises also to conduct on board incubation experiments with phytoplankton.

\section{$4 \quad$ Narrative of the Cruise}

RV ALKOR departed from GEOMAR pier on July $5^{\text {th }} 2020$ at 08:00 am and headed to the first research area in the Kiel Bight. 3 stations were realized, including a test of each individual gear. Within the Kiel Bight a massive abundance of jelly fish (Aurelia aurita and Cyanea capillata) was found, thus it was unfortunately impossible to use the fishery gears as planned.

As a reaction to miserable weather conditions, we were not able to steam towards the Bornholm Basin and during the next 2 days the working area was shifted into the Mecklenburg Bight.

Throughout the following 3 days (July $8^{\text {th }}-10^{\text {th }}$ ) distribution patterns of fish (focusing on Western Baltic Cod) along a depth gradient between the shallow basin extensions and the deep central Bornholm Basin were investigated by fishery hauls und corresponding hydrographic measurements via CTD.

Again unfavorable weather conditions interfered with the following work plan, after a short test no further station was conducted on July $11^{\text {th }}$.

Between July $12^{\text {th }}$ and July $15^{\text {th }}$ a comprehensive grid of zooplankton samples was conducted within the Bornholm Basin. A total amount of 45 stations were sampled with the Bongo net (3 different mesh sizes) and CTD hauls. Additionally, 6 stations within the sample area were investigated regarding the phytoplankton communities using a water sampler (Niskin bottle).

Normally, the station within the central Bornholm Basin with the highest number of found cod larvae (BB16, see map below) would have been sampled over a $24 \mathrm{~h}$ period ("24h-station") by 4 repetitions every 6 hours of each 2x Multinet-Maxi (horizontal) and 4x Multinet-Midi (vertical) to detect the differences in distribution patterns daytime wise. But again, due to restricted working conditions (weather and lower than normal scientific crew members) this $24 \mathrm{~h}$ station was also shifted to the following cruise AL540.

July $16^{\text {th }}$ and $17^{\text {th }}$ were successfully used to complete the planned fisheries within the Bornholm Basin, consisting of fishery hauls und corresponding hydrographic measurements via CTD.

During the last day of the cruise (July $18^{\text {th }}$ ) a final station within the Mecklenburg Bight was sampled by a fishery haul and a corresponding CTD measurement.

A detail on gear deployments (Table 4.1), the station list (Table 6.1), and an overview of first scientific results are provided below. 
Table 4.1: Overview of gear deployment. Mesh sizes are given in brackets.

\begin{tabular}{lr} 
Gear & Total \\
\hline ADM-CTD vertical & 78 \\
Bongo $(150 \mu \mathrm{m}, 335 \mu \mathrm{m}, 500 \mu \mathrm{m})$ & 45 \\
Pelagic fishery trawl & 19 \\
Bongo $(335 \mu \mathrm{m}, 500 \mu \mathrm{m})$ & 14 \\
Water sampler $($ Niskin Bottle) & 10 \\
\hline Total & 166
\end{tabular}

\section{$5 \quad$ Preliminary Results}

\subsection{Cruise Module}

(Luisa Listmann (PostDoc), Margarethe Nowicki (PhD), Richard Klinger (PhD) Hamburg University)

The module was structured in a specific way to impart knowledge as close as possible to the planned educational process during the cruise.

This resulted in a structured module, incorporating the following 4 objectives:

1 Creation of a variety of videos, covering all subject areas mentioned under " 3.2 Agenda of the Cruise" (defined responsibilities: I-IV), resulting in 12 topics (a-l, mentioned below) with a total of 14 videos (total length: 2,5h), which included added audio explanations.

a. Tour around the ship; including all labs and important areas

b. CTD; handling on deck and controls on the computer

c. Water sampler; handling on deck and controls on the computer

d. Plankton nets (Bongo, Multi net, WPS, Apstein); handling on deck and controls on the computer

e. Bongo in detail, gear and sample handling

f. Multi net in detail, gear and sample handling

g. Phytoplankton primary production; sample handling and following measurements

h. Jelly fish, handling jellies caught with plankton catching gears

i. Fish larvae; sorting and recognizing different species of larvae from bongo samples

j. Fisheries; usage of a trawl net; catch handling procedure

k. Sprat and herring; species identification, length measurements and stomach sampling

1. Cod; single fish analysis 
2 A quiz for every video topic, which has to be passed by the students

33 recorded lectures (total length: 3 h), serving background information with condensed information regarding:
a. The ecosystem Baltic Sea
b. Plankton sampling
c. Fisheries
d. Gears
e. Work on a research vessel
f. Introduction into handling CTD data using Ocean Data View

$4 \quad$ Working with data from recent cruises in groups of 3; resulting in an essay in the style of a scientific publication. Every group has to include hydrographic aspects into their thematic considerations. The following topics were assigned:
a. Hydrography of the Baltic Sea
b. Physiological response of phytoplankton communities to temperature changes
c. Physiological response of phytoplankton communities to salinity changes
d. Distribution and abundance changes of jelly fish
e. Distribution and abundance changes of cod eggs
f. Distribution and abundance changes of cod larvae
g. Distribution and abundance changes of zooplankton communities
h. Distribution and abundance changes of pelagic swarm fishes as sprat and herring
i. Distribution and physiological aspects regarding cod 

(Luisa Listmann (PostDoc), Maria Elisabetta Santelia (PhD), Elisa Schaum (Junior Prof.),
Hamburg University)

\section{Marine microbes and viruses of the Baltic Sea under climate change}

As part of this project on the ecological and evolutionary effects of different temperatures and salinities in the Baltic Sea on phytoplankton, we aim to answer the following questions: a) Does the acute physiological response of picoplankton to temperature and salinity differ between samples from different regions of the Baltic Sea? b) From which regions of the Baltic Sea can we isolate Ostreococcus sp. and its associated viruses? c) How do the immediate responses change in space and time (comparing data of different cruises of the last two years)?

To answer these questions, we took surface water samples at 10 stations along the cruise track of AL539. On board, we measured metabolism (photosynthesis and respiration) of two different size fractions of phytoplankton $(<0.45 \mu \mathrm{m}, 0.2-2 \mu \mathrm{m}$ and $0.2-37.5 \mu \mathrm{m})$ of 8 of the 10 stations immediately after sampling, and assessed these responses over a gradient of salinity and temperature. Furthermore, water samples of all stations and therof the two smaller size fractions were set aside to isolate viruses and picoplankton back in the laboratory at the institute in Hamburg. The 10 stations were divided into Kiel Bay, Mecklenburg Bay (considered together as Kiel Area) and the Bornholm Basin.

Preliminary analyses of the temperature curves (see Figures 5.1 A and 5.1 B) show that the size fractions and the interaction with different geographic locations, shape metabolic activity. In-depth analyses are ongoing, and point toward regional environmental forcing (e.g. comparisons between Bornholm Basin and Kiel Bight) having an impact on par with that of seasonal forcing (e.g. comparisons between different years and seasons). Our results suggest that while populations from either region can swiftly adjust their metabolic profiles along gradients of environmental change, the underlying mechanisms differ. For samples from the Bornholm Basin, rapid species sorting seems to explain most of the responses, whereas samples from Kiel Area tend to respond to environmental change through sorting within the same species and phenotypic plasticity (Santelia et al, in prep). On-going researches involve also testing directly the evolutionary potential under fluctuating conditions in an ongoing long-term experiment.

Comparable and further investigations were conducted in variety of theses, mentioning a published Master thesis outcome:

Zhong, D. Listmann, L., Santelia, M., Schaum, C. (2020), Biology Letters: Functional redundancy in natural pico-phytoplankton communities depends on temperature and biogeography. 
A

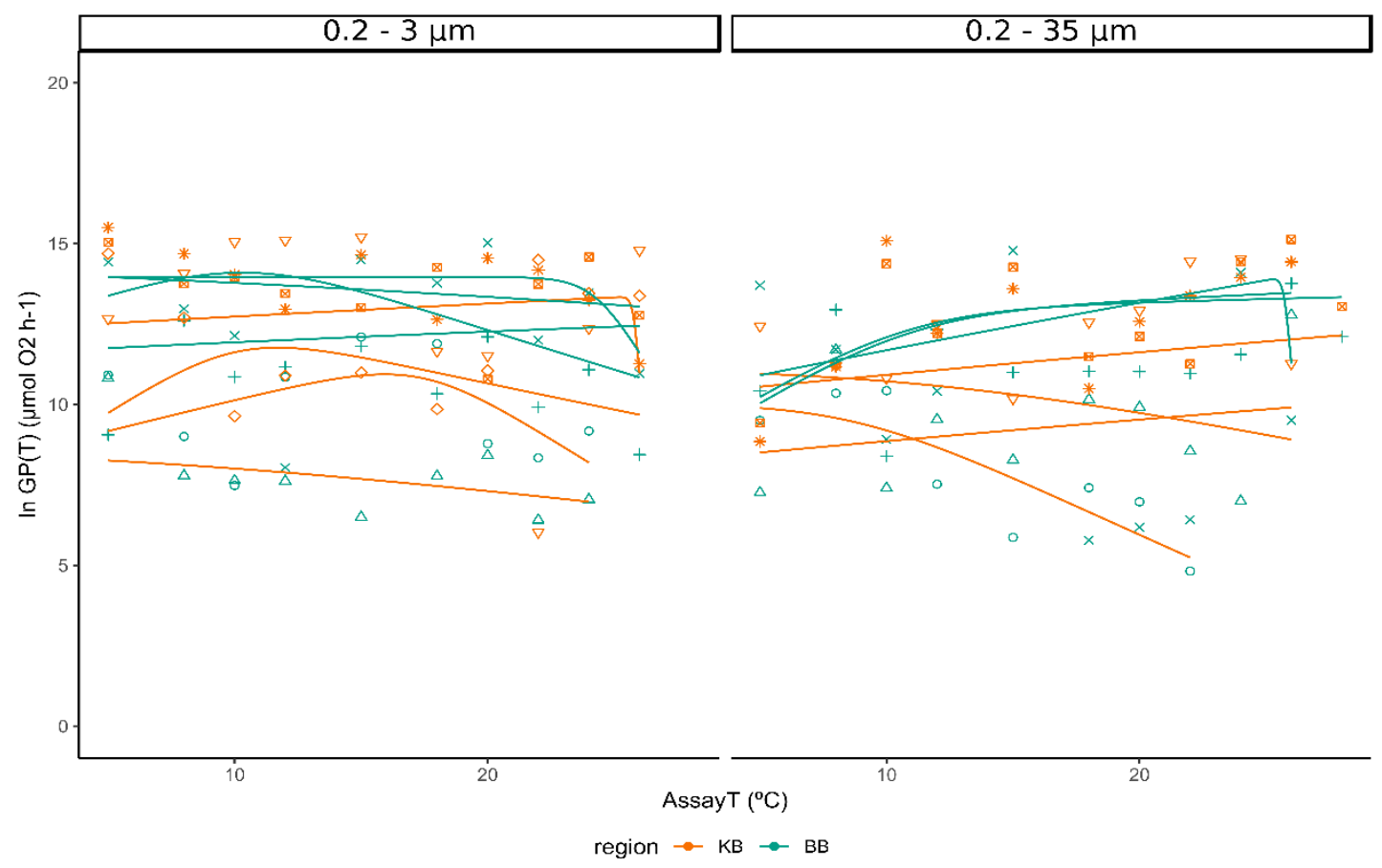

B

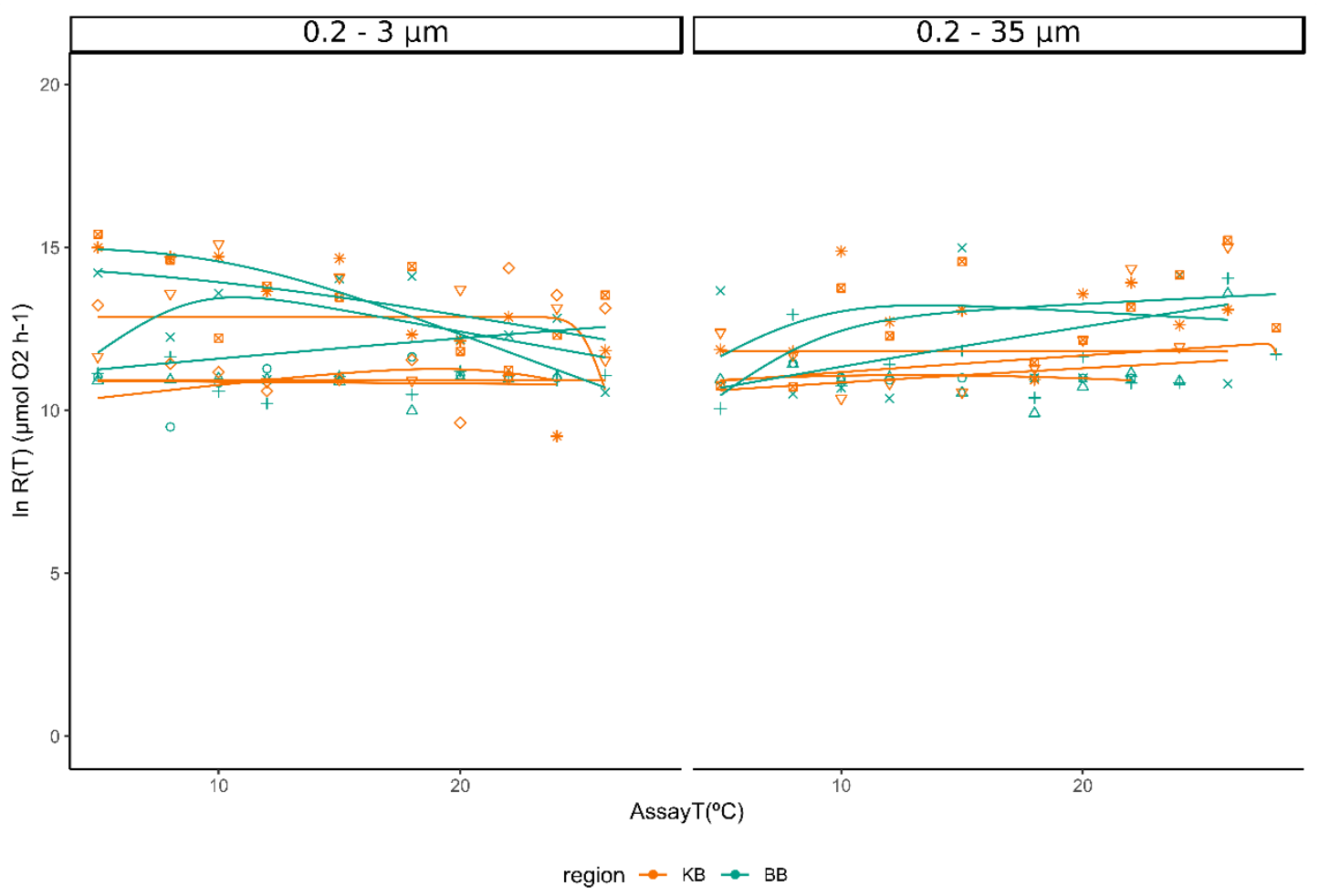

Figure 5.1: Temperature reaction norms from size fractioned on-board incubations of Kiel Bight and Bornholm samples across a temperature gradient $\left(5^{\circ} \mathrm{C}\right.$ up to $\left.26^{\circ} \mathrm{C}\right)$. A is for photosynthesis rates in $\mu \mathrm{mol}$ $\mathrm{O}_{2} \mathrm{~h}^{-1}$, and $\mathbf{B}$, for respiration rates in $\mu \mathrm{mol} \mathrm{O}_{2} \mathrm{~h}^{-1}$. Symbols denote different station, and the colours, as shown in the legend, characterize the different areas (KB: Kiel Bight; BB: Bornholm Basin). 
(Margarethe Nowicki (PhD), Richard Klinger (PhD), Hamburg University)

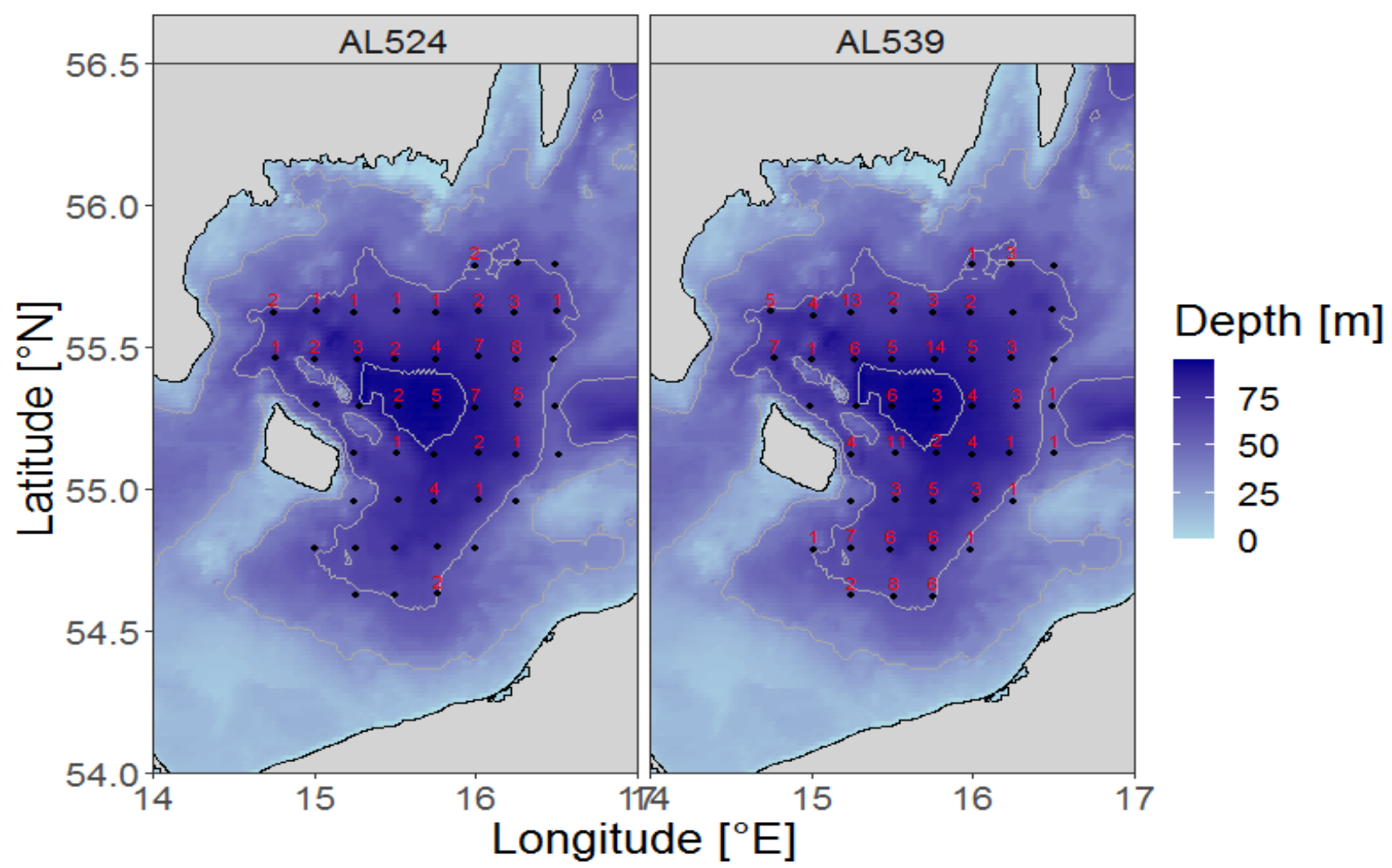

Figure 5.2: Overview of all processed bongo stations within the Bornholm-Basin during AL524 (July 2019) and AL539 (July 2020). Black dots represent bongo stations, red numbers are indicating the amount of cod larvae found within the corresponding Bongo samples. On stations without a number no cod larvae was found.

Within Bongo hauls covering the Bornholm Basin, cod larvae (Gadus morhua; $\mathrm{n}=163$ in total) were picked from the $500 \mu \mathrm{m}$ bongo-samples and conserved at $-80^{\circ} \mathrm{C}$ for subsequent RNA/DNA analyses (collaboration with Dr. Bastian Huwer, DTU Aqua). The spatial distribution of cod larvae during July 2019 (AL524) and July 2020 (AL539) is presented in Figure 5.2. Highest density was found within the central part of the Bornholm Basin.

During our last summer cruises, the total number of found cod larvae increased significantly from 18 individuals in 2018, to 71 during 2019, up to 163 in 2020.

All of the $335 \mu \mathrm{m}$ Bongo und the $300 \mu \mathrm{m}$ Multinet samples were also checked for the presence of fish eggs. Following these initial on-board steps, all Bongo samples were conserved in $4 \%$ buffered formol solution, and will be used for the determination of species composition and abundance of zooplankton and ichthyoplankton. 
5.3 Fishery

(Richard Klinger (PhD), Steffen Funk (Post-Doc), Hamburg University)

Fishery hauls were conducted in the Kiel Bight (1 haul), Mecklenburg Bight (3 hauls), as well as Bornholm Basin including 15 hauls.

In parallel to the fishery hauls, hydroacoustic measurements of fish distribution patterns were recorded continuously.

The overall catch composition is shown in Table 5.1.

Table 5.1: Fish catch composition AL539.

\begin{tabular}{llrr} 
Latin name & Common name & n & mass (kg) \\
\hline Sprattus sprattus & Sprat & 13473 & 175.5 \\
Clupea harengus & Herring & 4774 & 134.2 \\
Gadus morhua & Cod & 1922 & 525.4 \\
Juvenil Gadus morhua & Juvenile Cod & 284 & 0.9 \\
Gasterosteus aculeatus & Three-spined Stickleback & 199 & 0.4 \\
Hyperoplus lanceolatus & Great sand eel & 73 & 1.0 \\
Merlangius merlangus & Whiting & 35 & 2.8 \\
Scomber scombrus & Mackerel & 24 & 3.0 \\
Limanda limanda & Dab & 23 & 2.5 \\
Platichthys flesus & Flounder & 14 & 2.8 \\
Rhinonemus cimbrius & Four-bearded rockling & 3 & 0.1 \\
Engraulis encrasicolus & Anchovy & 2 & 0.0 \\
Cyclopterus lumpus & Lumpfish & 1 & 0.3 \\
Pleuronectes platessa & Plaice & 1 & 0.1 \\
Scyphozoa spec. & "True" jellyfish & & 1000.0 \\
\hline & Total & 20828 & 1852
\end{tabular}

For each haul and the entire catch, catch weight and length frequencies of all species were determined. Stomach samples were taken from sprat (30 per $1 \mathrm{~cm}$ length class) and herring (30 per $2 \mathrm{~cm}$ length class).

For cod, single fish data (length, weight, liver weight, liver worm infestation, sex and maturity stage) as well as samples (otoliths and stomach) were obtained for 380 individuals, whereas length, weight, liver weight, liver worm infestation, sex and maturity stage (without samples taken) were measured for 545 individuals. Length, weight and sex were determined for another 997 individuals (juveniles are not included). 


\subsubsection{Stomach samplings}

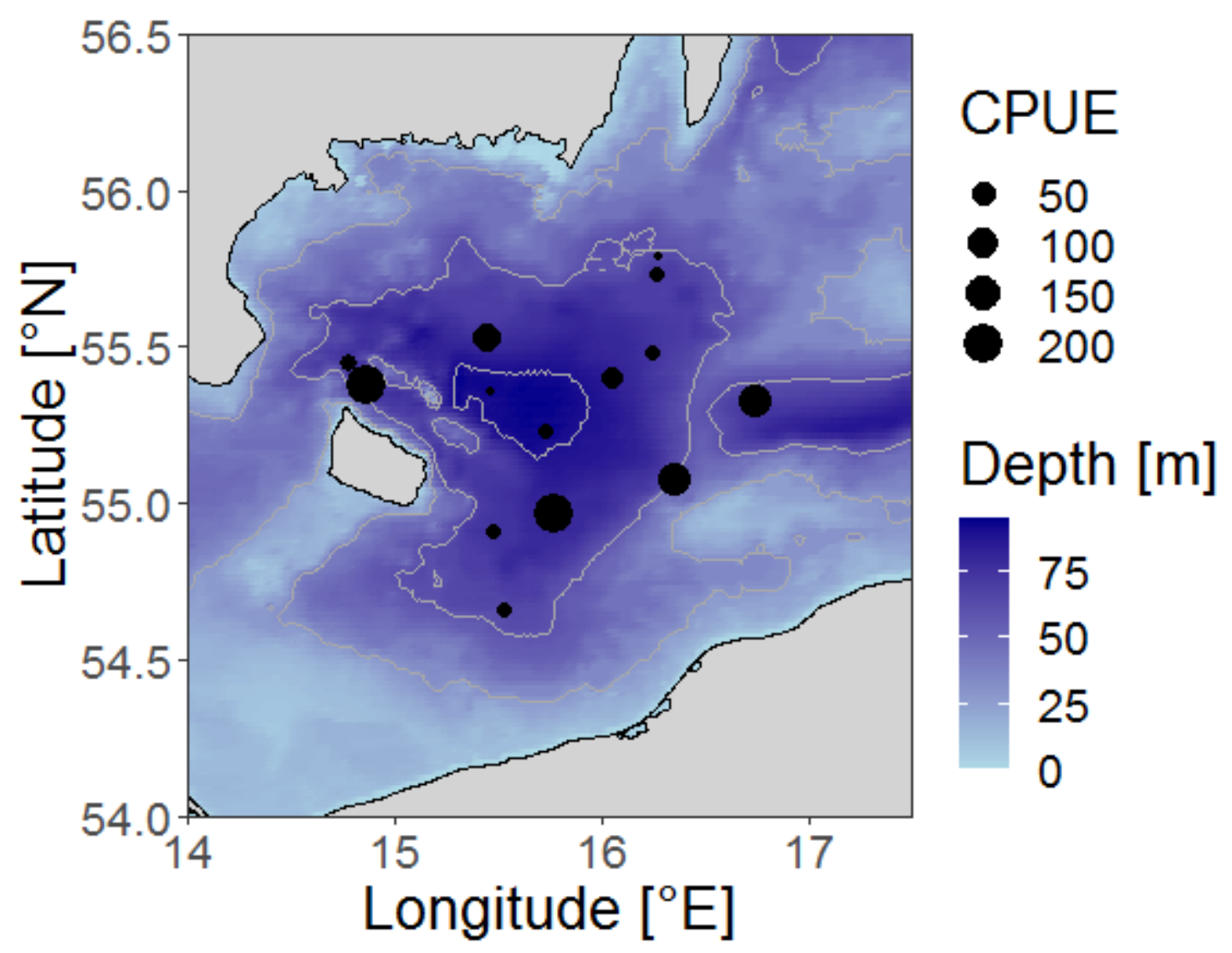

Figure 5.3: Spatial distribution of cod, caught per hour in $\mathrm{kg}(\mathrm{CPUE}=$ Catch per unit effort $)$ during AL539.

Routine stomach samplings are conducted during the research surveys in cooperation with the Thünen Institute of Baltic Sea Fisheries which focus on cod (Gadus morhua), whiting (Merlangius merlangus), flounder (Platichthys flesus) and plaice (Pleuronectes platessa). Figure 5.3 shows the spatial distribution of caught cod during AL539. Aim of the stomach sampling projects starting in 2016 is the investigation of feeding ecology of key predators in the Baltic Sea, whereby the sampling especially focuses on depth and habitat related patterns in the diet compositions. A year-round depth stratified sampling in 2016 revealed depth specific, seasonal and ontogenetic effects in the diet composition of cod in the Western Baltic Sea and provided as a pilot study the basis for the still ongoing depth stratified sampling in the eastern Baltic Sea. Two master theses (Peter Hornetz, Tobias Reßing) and one PhD thesis (Steffen Funk) were conducted, beeing involved in the stomach sampling project. 


\subsection{2. $\quad$ Single fish cod sampling}

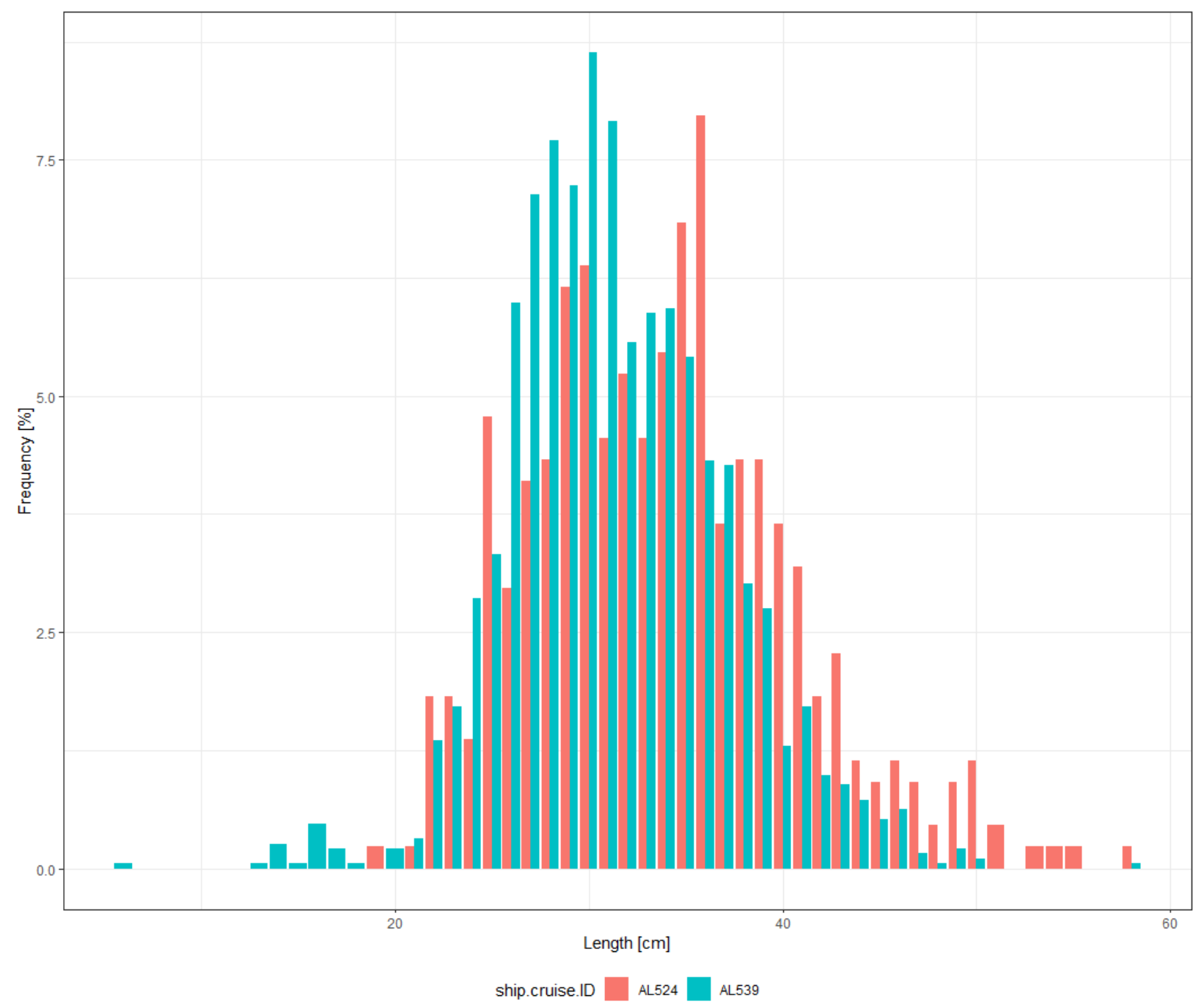

Figure 5.4: Relative length frequency distribution of individual sampled cod in 2019 (AL524; $n=440$ ) and 2020 (AL539; $\mathrm{n}=1922$ ). Frequency is given in percent and length in $\mathrm{cm}$ (measurement $\mathrm{cm}$ below).

Relative length frequency distribution of individual sampled cod within the Bornholm Basin during 2019 (AL524) and 2020 (AL539) is shown in Figure 5.4.

Comparing the length frequency distribution between the July cruises in 2019 and 2020 reveal a shift towards smaller fish within the present cruise. Differences in spatial sampling might explain this shift, but nevertheless no fish bigger than $60 \mathrm{~cm}$ was caught.

Figure 5.5 shows the condition factor Fulton`s $K$ for all sampled cod per $10 \mathrm{~cm}$ length classes (LC) $(11-20 \mathrm{~cm} ; 21-30 \mathrm{~cm}$; aso). Fulton`s $K$ Index is calculated as the somatic weight in $\mathrm{g}$ (gutted weight) and the total length in $\mathrm{cm}$ (Lambert and Dutil, 1996). There are no significant differences in the condition of individual cod, only within LC $41-50 \mathrm{~cm}$ caught cod of 2020 show a significant decreased condition. These results are consistent with previous observations.

Another PhD thesis (Richard Klinger) focuses on the combination of single fish data gained from various research cruises with results of experimental studies regarding Baltic cod feeding on natural diets in recirculating water systems. This represents a basis of physiological data which will be completed with the stomach content data of the mentioned studies to create a bioenergetic growth model of eastern Baltic cod. 


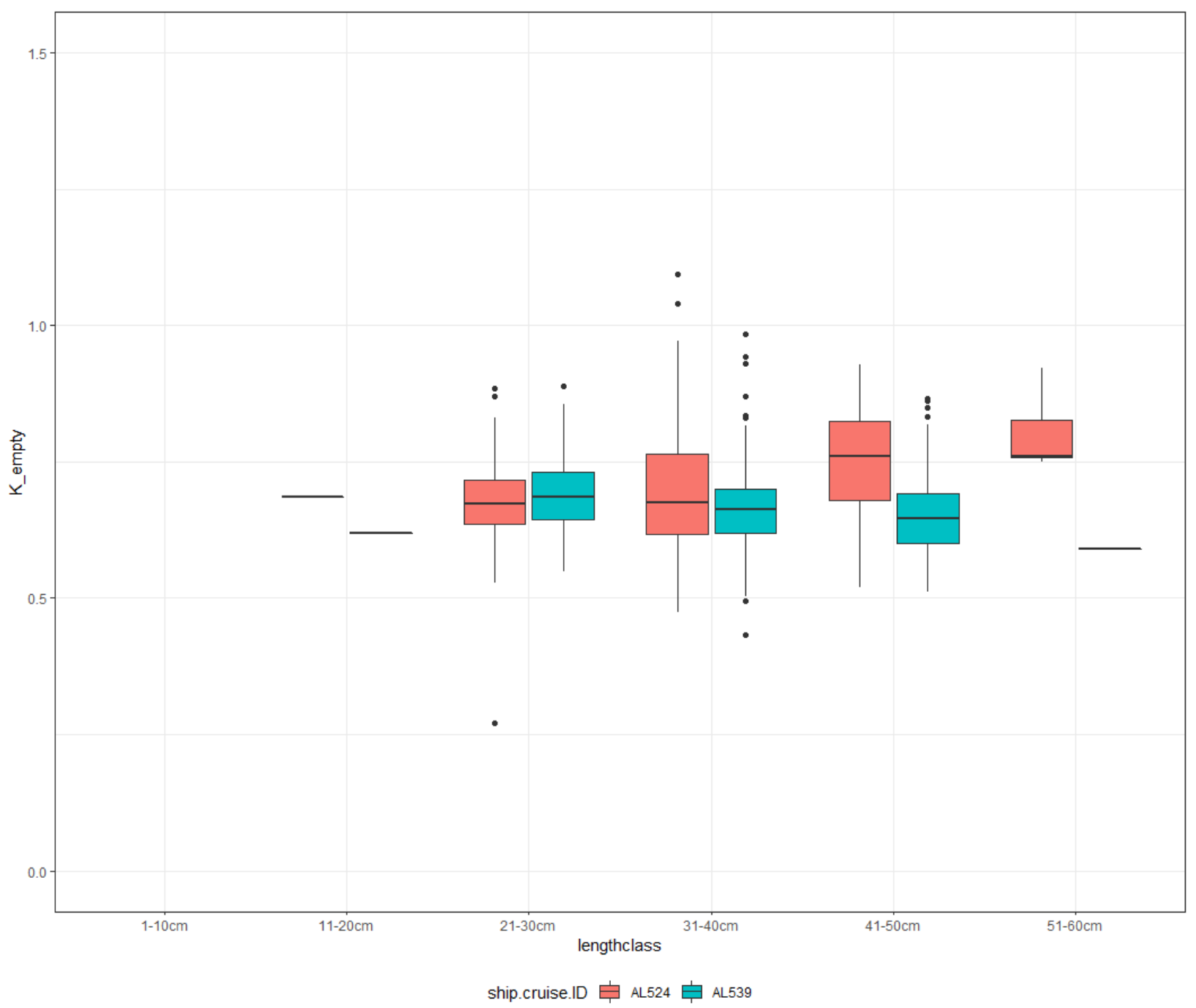

Figure 5.5: Fulton's K Index of individual sampled cod during AL524 (July 2019) in red and AL539 (July 2020) in blue, of all caught cod within the Bornholm Basin.

As the cruise is conducted during the main spawning season of Eastern Baltic Cod (EBC) a special interest applies the distribution of the maturity stages of cod, as an important key species in the Baltic Sea.

Figure 5.6 shows the frequency of grouped maturity stages per $10 \mathrm{~cm} \mathrm{LC}$ for females and males within the Bornholm Basin during the cruises AL524 (July 2019) and AL539 (July 2020). Comparing the results of both years, no major difference in the maturity distribution was found. The Bornholm Basin represents the main spawning area of EBC, which can be seen in the graph below, during both years maturity stages 5-7 representing spawning were most frequent in almost every LC. 


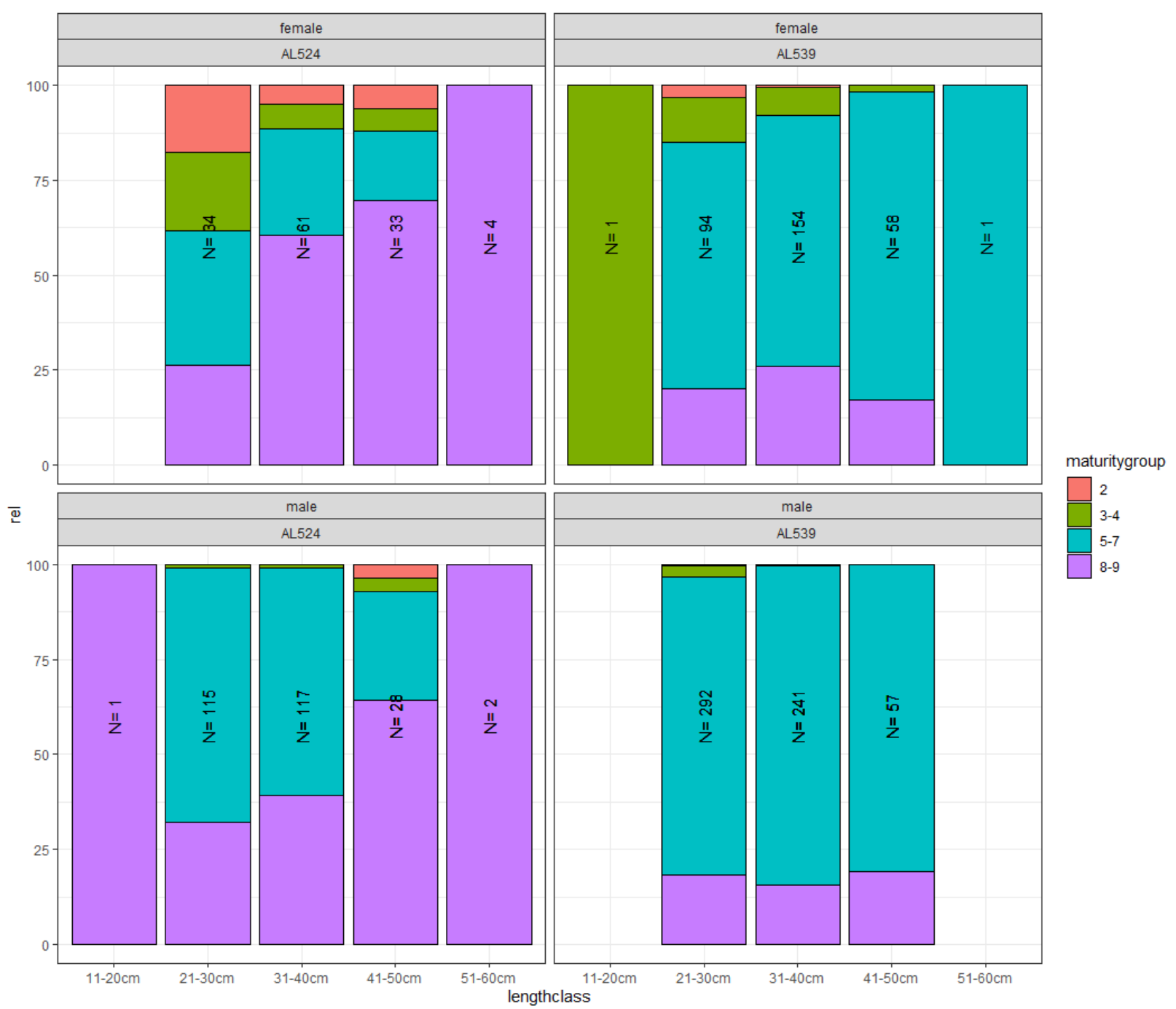

Figure 5.6: Relative frequency distribution in percent of the grouped maturity stages per $10 \mathrm{~cm}$ length class shown for individual sampled female and male cod during AL524 (July 2019) left hand column and AL539 (July 2020) right hand column. Maturity stages Red: 1-2 (juvenile and preparation); Green: Maturity stage 3-4 (maturation); Cyan: Maturity stage 5-7 (spawning); Purple: Maturity stage 8-9 (regeneration).

During the past decade infestation rates of cod liver worms (nematodes) became more and more frequent. So far there is only little knowledge about the infestation effects on physiological aspects within Baltic cod. Some studies where able to show a correlation between infestation rates and reduced condition. Therefore, it is mandatory to investigate the long-term changes of infestation and compare results between different cruises, seasons and years. Figure 5.7. shows the relative frequency distribution in percent of liver worm (Nematodes) infestation stages (visible on liver surface) per $10 \mathrm{~cm}$ length class shown for individual sampled female and male cod during AL524 (July 2019) left hand column and AL539 (July 2020) right hand column. Infestation is determined by visual determination of nematodes on the liver surface: stage $0=$ nematodes; stage $1=1-10$ nematodes; stage $2=11-20$ nematodes and stage $3=>20$ nematodes. Comparing both summer cruises (AL524 and AL539) regarding the mentioned infestation rates, no major change is notable. This represents a trend that has been observed throughout the last years, but the rather small sample size during AL524 might also be a reason for the mentioned observation from Figure 5.7. 


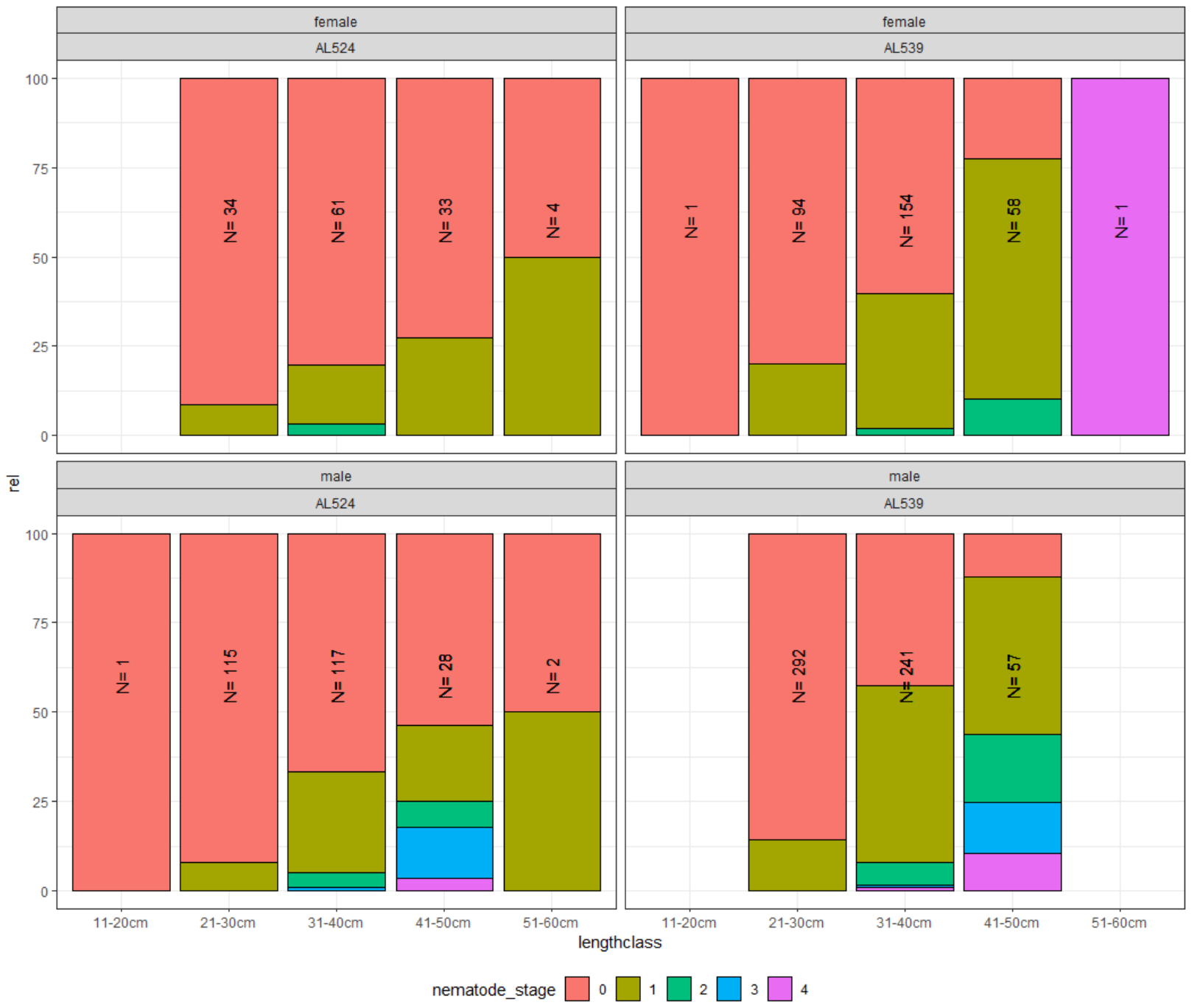

Figure 5.7: Relative frequency distribution in percent of liver worm (Nematodes) infestation stages (visible on liver surface) per $10 \mathrm{~cm}$ length class shown for individual sampled female and male cod during AL524 (July 2019) left hand column and AL539 (July 2020) right hand column. Infestation stages Red: 0 (0 nematodes); Green: stage 1 (1-10 nematodes); Cyan: stage 2 (11-20 nematodes); Purple: stage 3 (more than 20 nematodes). 


\section{4}

\section{Hydrography}

(Jens-Peter Herrmann (Scientific employee), Richard Klinger (PhD), Hamburg University)

\subsubsection{Mecklenburg Bight}

As expected, a strong salinity gradient from west (coastal waters of island Fehmarn) to east was detected (Figure $5.8 \mathrm{~b}$ ). At the surface the salinity ranged from 13,5 PSU in the western part of the Mecklenburg Bight to 12 PSU in the eastern part. Near the bottom the salinity was higher with 24 PSU in the west and 16 to 17 PSU in the east indicating a stratified water column. The temperature distribution (Figure 5.8. a) showed a uniform warmer layer from the surface to ca. $20 \mathrm{~m}$ depth over the hole area. With its $16^{\circ} \mathrm{C}$ to $18^{\circ} \mathrm{C}$ the summer surface temperature was comparable to former years. The pattern of Chlorophyll A (ChlA) (Figure $5.8 \mathrm{c}$ ) showed always a maximum at the thermocline with highest values in the eastern part.

The oxygen distribution (Figure $5.8 \mathrm{~d}$ ) resulted in nearly saturated surface water masses along the transect. Near bottom the oxygen saturation was slightly depleted where stronger salinity stratifications were observed in the deeper parts of Mecklenburg Bight with lowest values around $40 \%$ and $50 \%$. Indicating that the water masses in these areas are of certain age.

a)

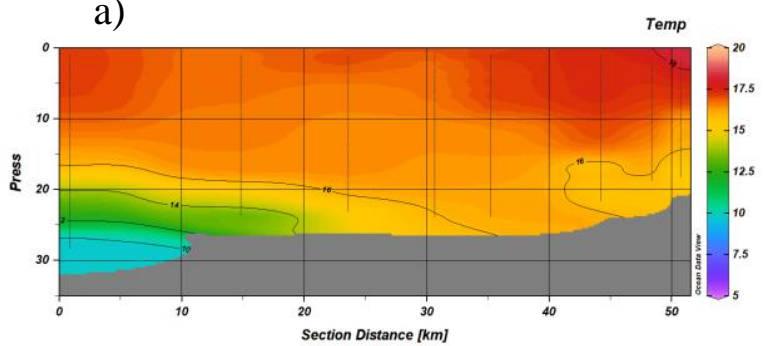

c)

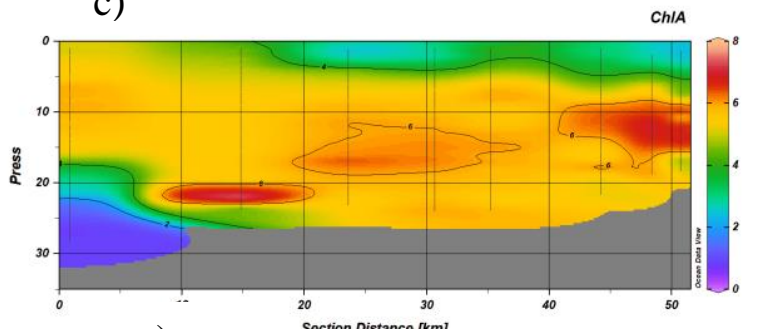

e)

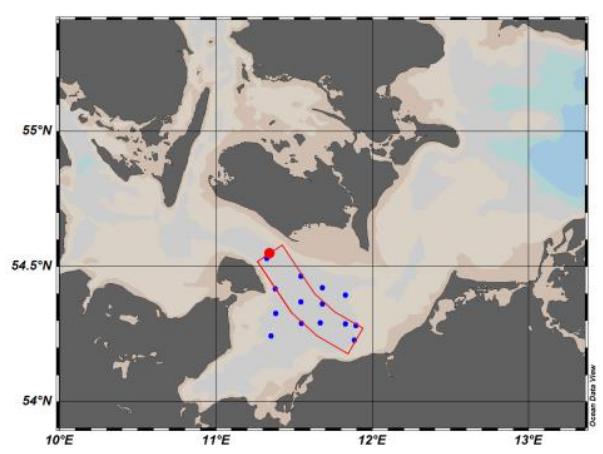

b)

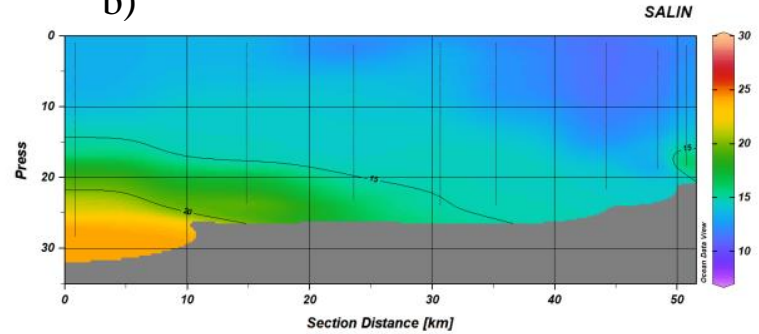

d)

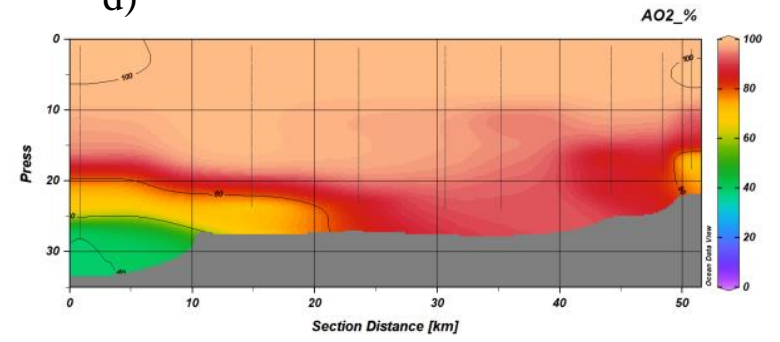

AL539

Hydrography along a transect Within the Mecklenburg Bight

Figure 5.8: Station map and hydrographic isoplots of the cruise AL539 along a transect within the Mecklenburg Bight 


\subsubsection{Bornholm Basin}

Within the Bornholm Basin the hydrography was relative uniform with only slightly higher surface temperatures in the southern most part (Figure 5.9 a). The salinity ranged from 7 to 9 PSU in the upper $30 \mathrm{~m}$ of the water column and values between 11 and 17 PSU in the deeper parts (Figure $5.9 \mathrm{~b}$, Figure $5.10 \mathrm{~b}$ ). The halocline was found in deeper waters within the east $(60 \mathrm{~m})$ than in the west $(50 \mathrm{~m})$ (Figure $5.10 \mathrm{~b}$ ). The distribution of oxygen saturation showed a very similar pattern with nearly $100 \%$ saturation in the upper water column and decreasing values down to $0 \%$ below the halocline $(70 \mathrm{~m})$ where salinity was highest (Figure $5.9 \mathrm{~d}$, Figure $5.10 \mathrm{~d})$. Only in the southern part temperature was slightly higher in the upper water column compared to the rest (Figure 5.9 b). The chlorophyll data revealed relatively low values indicating that the summer minimum nutrient in this area was established (Figure $5.9 \mathrm{c}$, Figure $5.10 \mathrm{c})$.

a)

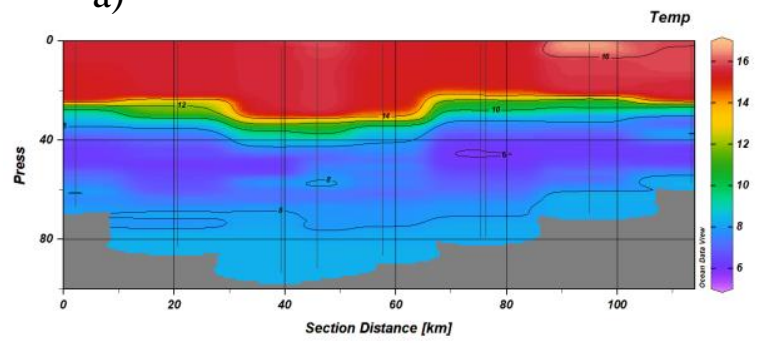

c)

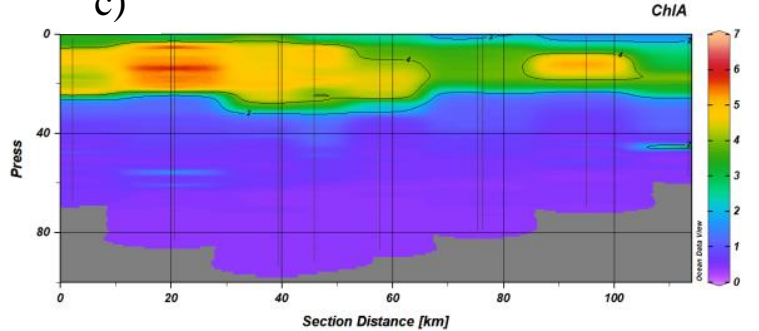

e)

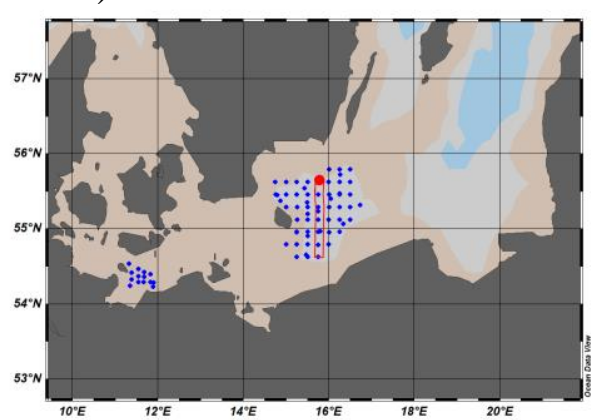

b)

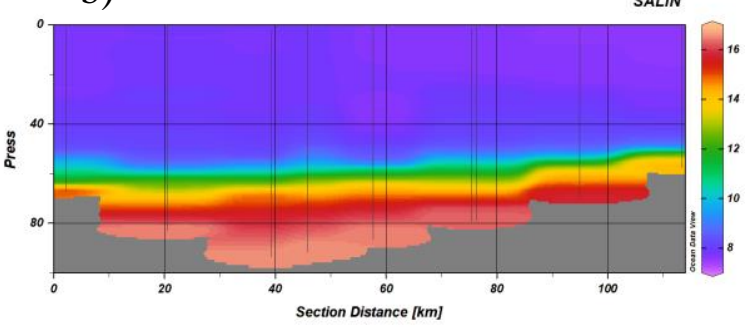

d)

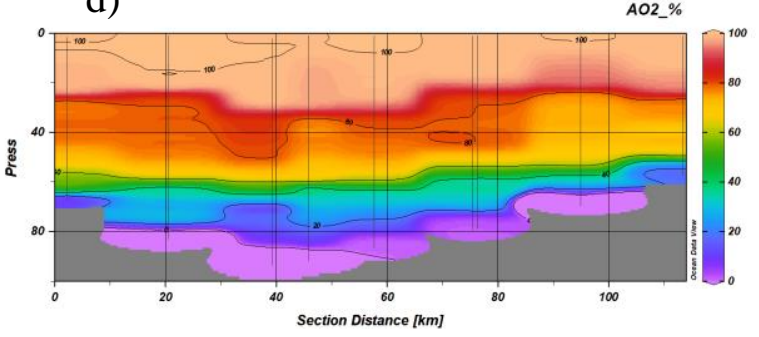

AL539

Hydrography along a transect from south to north in the Bornholm Basin

Figure 5.9: Station map and hydrographic isoplots of the cruise AL539 along a transect from south to north in the Bornholm Basin. 
a)

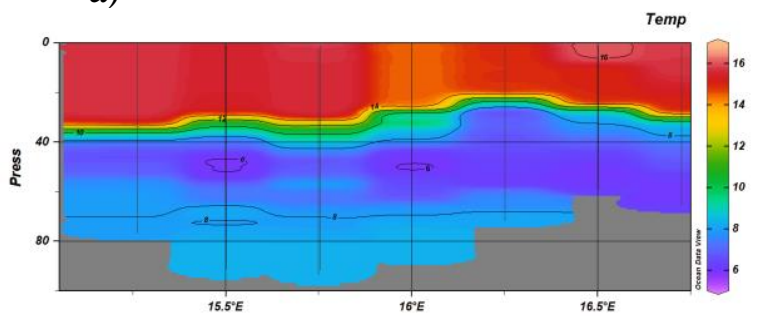

c)

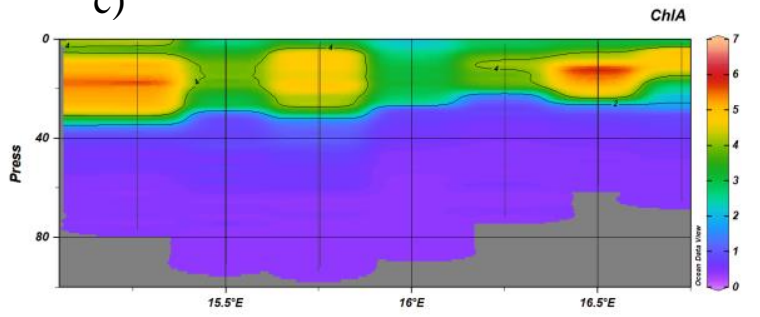

e)

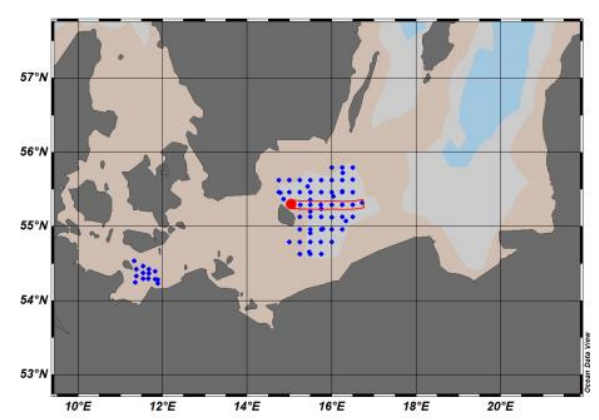

b)

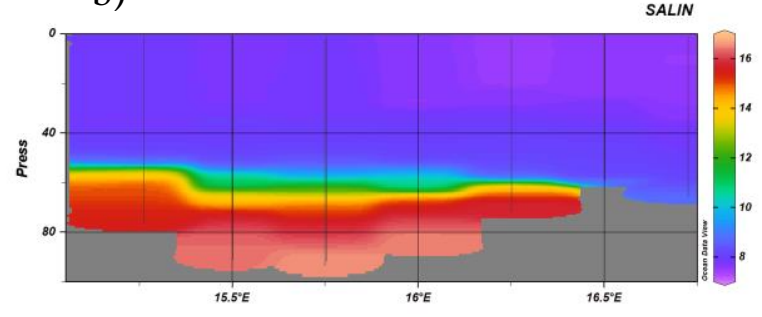

d)

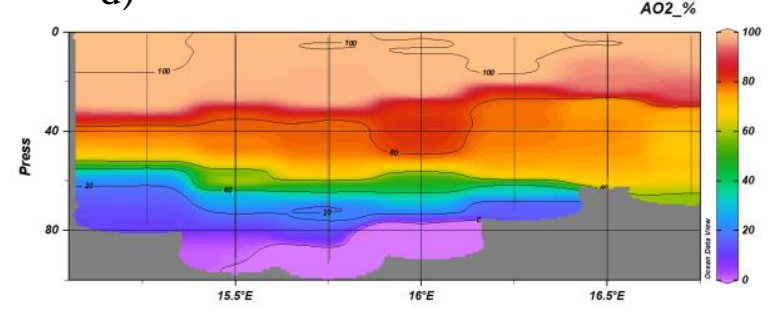

AL539

Hydrography along a transect from west to east in the Bornholm Basin

Figure 5.10: Station map and hydrographic isoplots of the cruise AL539 along a transect from west to east in the Bornholm Basin. 


\section{$6 \quad$ Station List AL539}

\subsection{Overall Station List}

Table 6.1: Start positions for all used gears are given (in action log noted as "in water"). For fishing the "Start Fishing" positions are listed.

\begin{tabular}{|c|c|c|c|c|c|c|c|}
\hline Station No. & Date & Gear & Time & Latitude & Longitude & $\begin{array}{l}\text { Water } \\
\text { Depth }\end{array}$ & $\begin{array}{l}\text { Remarks/ } \\
\text { Recovery }\end{array}$ \\
\hline ALKOR & 2019 & & [UTC] & {$\left[{ }^{\circ} \mathbf{N}\right]$} & {$\left[{ }^{\circ} \mathbf{W}\right]$} & [m] & \\
\hline AL539_1-1 & $07: 40$ & CTD & 05.07. & $54^{\circ} 32,028^{\prime} \mathrm{N}$ & $010^{\circ} 04,033^{\prime} \mathrm{E}$ & 23 & \\
\hline AL539_1-2 & $08: 26$ & Niskin Bottle & 05.07. & $54^{\circ} 32,013^{\prime} \mathrm{N}$ & $010^{\circ} 04,117^{\prime} \mathrm{E}$ & 23 & \\
\hline AL539_2-1 & 09:51 & Bongo Net & 05.07. & $54^{\circ} 33,902^{\prime} \mathrm{N}$ & $010^{\circ} 12,074^{\prime} \mathrm{E}$ & 16 & \\
\hline AL539_2-2 & 10:03 & CTD & 05.07. & $54^{\circ} 33,803^{\prime} \mathrm{N}$ & $010^{\circ} 11,899^{\prime} \mathrm{E}$ & 16 & \\
\hline AL539_2-3 & 10:08 & Fish Net & 05.07 . & $54^{\circ} 33,794^{\prime} \mathrm{N}$ & $010^{\circ} 11,878^{\prime} \mathrm{E}$ & 16 & \\
\hline AL539_3-1 & 13:29 & CTD & 05.07. & $54^{\circ} 39,112^{\prime} \mathrm{N}$ & $010^{\circ} 39,953^{\prime} \mathrm{E}$ & 19 & \\
\hline AL539_3-2 & $13: 43$ & Niskin Bottle & 05.07. & $54^{\circ} 39,054^{\prime} \mathrm{N}$ & $010^{\circ} 39,994^{\prime} \mathrm{E}$ & 20 & \\
\hline AL539_3-3 & $13: 49$ & Bongo Net & 05.07 . & $54^{\circ} 39,010^{\prime} \mathrm{N}$ & $010^{\circ} 39,971^{\prime} \mathrm{E}$ & 22 & \\
\hline AL539_4-1 & 06:03 & Bongo Net & 06.07. & $54^{\circ} 32,030^{\prime} \mathrm{N}$ & $011^{\circ} 19,675^{\prime} \mathrm{E}$ & 25 & \\
\hline AL539_4-2 & $06: 13$ & CTD & 06.07. & $54^{\circ} 31,912^{\prime} \mathrm{N}$ & $011^{\circ} 19,351^{\prime} \mathrm{E}$ & 26 & \\
\hline AL539_4-3 & $06: 48$ & Fish Net & 06.07 . & $54^{\circ} 28,734^{\prime} \mathrm{N}$ & $011^{\circ} 23,818^{\prime} \mathrm{E}$ & 23 & \\
\hline AL539_5-1 & 08:50 & CTD & 06.07. & $54^{\circ} 25,192^{\prime} \mathrm{N}$ & $011^{\circ} 22,617^{\prime} \mathrm{E}$ & 16 & \\
\hline AL539_5-2 & $08: 56$ & Niskin Bottle & 06.07. & $54^{\circ} 25,192^{\prime} \mathrm{N}$ & $011^{\circ} 22,558^{\prime} \mathrm{E}$ & 16 & \\
\hline AL539_6-1 & 13:10 & Bongo Net & 06.07. & $54^{\circ} 19,779^{\prime} \mathrm{N}$ & $011^{\circ} 23,144^{\prime} \mathrm{E}$ & 17 & \\
\hline AL539_6-2 & 13:18 & CTD & 06.07. & $54^{\circ} 19,697^{\prime} \mathrm{N}$ & $011^{\circ} 22,744^{\prime} \mathrm{E}$ & 17 & \\
\hline AL539_7-1 & $13: 58$ & CTD & 06.07 . & $54^{\circ} 14,674^{\prime} \mathrm{N}$ & $011^{\circ} 20,914^{\prime} \mathrm{E}$ & 17 & \\
\hline AL539_7-2 & 14:08 & Bongo Net & 06.07. & $54^{\circ} 14,550^{\prime} \mathrm{N}$ & $011^{\circ} 20,557^{\prime} \mathrm{E}$ & 17 & \\
\hline AL539_8-1 & 06:01 & Bongo Net & 07.07. & $54^{\circ} 27,736^{\prime} \mathrm{N}$ & $011^{\circ} 33,097^{\prime} \mathrm{E}$ & 21 & \\
\hline AL539_8-2 & $06: 27$ & CTD & 07.07. & $54^{\circ} 27,885^{\prime} \mathrm{N}$ & $011^{\circ} 32,475^{\prime} \mathrm{E}$ & 21 & \\
\hline AL539_9-1 & 07:08 & CTD & 07.07. & $54^{\circ} 25,417^{\prime} \mathrm{N}$ & $011^{\circ} 40,606^{\prime} \mathrm{E}$ & 20 & \\
\hline AL539_9-2 & 07:18 & Niskin Bottle & 07.07. & $54^{\circ} 25,445^{\prime} \mathrm{N}$ & $011^{\circ} 40,575^{\prime} \mathrm{E}$ & 20 & \\
\hline AL539_9-3 & $07: 25$ & Bongo Net & 07.07. & $54^{\circ} 25,399^{\prime} \mathrm{N}$ & $011^{\circ} 40,643^{\prime} \mathrm{E}$ & 20 & \\
\hline AL539_10-1 & 08:09 & Bongo Net & 07.07. & $54^{\circ} 23,813^{\prime} \mathrm{N}$ & $011^{\circ} 49,943^{\prime} \mathrm{E}$ & 17 & \\
\hline AL539_10-2 & 08:18 & CTD & 07.07. & $54^{\circ} 23,756^{\prime} \mathrm{N}$ & $011^{\circ} 49,586^{\prime} \mathrm{E}$ & 17 & \\
\hline AL539_11-1 & 08:59 & CTD & 07.07. & $54^{\circ} 21,723^{\prime} \mathrm{N}$ & $011^{\circ} 40,653^{\prime} \mathrm{E}$ & 21 & \\
\hline AL539_11-2 & 09:06 & Bongo Net & 07.07. & $54^{\circ} 21,657^{\prime} \mathrm{N}$ & $011^{\circ} 40,536^{\prime} \mathrm{E}$ & 21 & \\
\hline AL539_12-1 & 09:42 & Bongo Net & 07.07. & $54^{\circ} 22,304^{\prime} \mathrm{N}$ & $011^{\circ} 32,885^{\prime} \mathrm{E}$ & 21 & \\
\hline AL539_12-2 & 09:50 & CTD & 07.07. & $54^{\circ} 22,251^{\prime} \mathrm{N}$ & $011^{\circ} 32,554^{\prime} \mathrm{E}$ & 21 & \\
\hline AL539_13-1 & \begin{tabular}{|l|}
$10: 32$ \\
\end{tabular} & CTD & 07.07. & $54^{\circ} 17,473^{\prime} \mathrm{N}$ & $011^{\circ} 32,620^{\prime} \mathrm{E}$ & 20 & \\
\hline AL539_13-2 & $10: 46$ & Bongo Net & 07.07 . & $54^{\circ} 17,351^{\prime} \mathrm{N}$ & $011^{\circ} 32,657^{\prime} \mathrm{E}$ & 20 & \\
\hline AL539_14-1 & $11: 24$ & Bongo Net & 07.07. & $54^{\circ} 17,766^{\prime} \mathrm{N}$ & $011^{\circ} 40,089^{\prime} \mathrm{E}$ & 22 & \\
\hline AL539_14-2 & $11: 32$ & CTD & 07.07. & $54^{\circ} 17,627^{\prime} \mathrm{N}$ & $011^{\circ} 39,942^{\prime} \mathrm{E}$ & 21 & \\
\hline AL539_15-1 & $12: 11$ & CTD & 07.07. & $54^{\circ} 17,305^{\prime} \mathrm{N}$ & $011^{\circ} 49,465^{\prime} \mathrm{E}$ & 19 & \\
\hline AL539_15-2 & $12: 17$ & Bongo Net & 07.07. & $54^{\circ} 17,234^{\prime} \mathrm{N}$ & $011^{\circ} 49,424^{\prime} \mathrm{E}$ & 19 & \\
\hline AL539_16-1 & 13:05 & Fish Net & 07.07. & $54^{\circ} 17,648^{\prime} \mathrm{N}$ & $011^{\circ} 56,121^{\prime} \mathrm{E}$ & 15 & \\
\hline AL539_16-2 & 13:54 & CTD & 07.07. & $54^{\circ} 16,952^{\prime} \mathrm{N}$ & $011^{\circ} 53,554^{\prime} \mathrm{E}$ & 16 & \\
\hline AL539_17-1 & 06:01 & Fish Net & 08.07. & $54^{\circ} 39,518^{\prime} \mathrm{N}$ & $015^{\circ} 32,656^{\prime} \mathrm{E}$ & 63 & \\
\hline AL539_17-2 & 07:13 & CTD & 08.07. & $54^{\circ} 39,365^{\prime} \mathrm{N}$ & $015^{\circ} 27,966^{\prime} \mathrm{E}$ & 61 & \\
\hline AL539_18-1 & 09:19 & CTD & 08.07. & $54^{\circ} 54,395^{\prime} \mathrm{N}$ & $015^{\circ} 30,070^{\prime} \mathrm{E}$ & 73 & \\
\hline AL539_18-2 & 09:27 & Fish Net & 08.07. & $54^{\circ} 54,395^{\prime} \mathrm{N}$ & $015^{\circ} 29,961^{\prime} \mathrm{E}$ & 73 & \\
\hline
\end{tabular}




\begin{tabular}{|c|c|c|c|c|c|c|}
\hline AL539_19-1 & $13: 23$ & CTD & 08.07. & $55^{\circ} 11,745^{\prime} \mathrm{N}$ & $015^{\circ} 30,037^{\prime} \mathrm{E}$ & 64 \\
\hline AL539_19-2 & $13: 32$ & Fish Net & 08.07. & $55^{\circ} 11,741^{\prime} \mathrm{N}$ & $015^{\circ} 29,819^{\prime} \mathrm{E}$ & 10 \\
\hline AL539_20-1 & 06:00 & CTD & 09.07. & $54^{\circ} 57,995^{\prime} \mathrm{N}$ & $015^{\circ} 47,651^{\prime} \mathrm{E}$ & 80 \\
\hline AL539_20-2 & $06: 10$ & Fish Net & 09.07. & $54^{\circ} 58,007^{\prime} \mathrm{N}$ & $015^{\circ} 47,443^{\prime} \mathrm{E}$ & 79 \\
\hline AL539_21-1 & 09:30 & CTD & 09.07. & $55^{\circ} 13,978^{\prime} \mathrm{N}$ & $015^{\circ} 45,236^{\prime} \mathrm{E}$ & 92 \\
\hline AL539_21-2 & 09:37 & Fish Net & 09.07. & $55^{\circ} 13,933^{\prime} \mathrm{N}$ & $015^{\circ} 45,218^{\prime} \mathrm{E}$ & 92 \\
\hline AL539_22-1 & $12: 44$ & \begin{tabular}{|l|} 
CTD \\
\end{tabular} & 09.07. & $55^{\circ} 32,312^{\prime} \mathrm{N}$ & $015^{\circ} 25,890^{\prime} \mathrm{E}$ & 72 \\
\hline AL539_22-2 & $12: 53$ & Fish Net & 09.07. & $55^{\circ} 32,248^{\prime} \mathrm{N}$ & $015^{\circ} 25,979^{\prime} \mathrm{E}$ & 72 \\
\hline AL539_23-1 & 06:01 & CTD & 10.07. & $55^{\circ} 47,493^{\prime} \mathrm{N}$ & $016^{\circ} 15,291^{\prime} \mathrm{E}$ & 58 \\
\hline AL539_23-2 & $06: 10$ & Fish Net & 10.07. & $55^{\circ} 47,506^{\prime} \mathrm{N}$ & $016^{\circ} 15,347^{\prime} \mathrm{E}$ & 57 \\
\hline AL539_24-2 & $07: 52$ & CTD & 10.07. & $55^{\circ} 43,294^{\prime} \mathrm{N}$ & $016^{\circ} 15,641^{\prime} E$ & 63 \\
\hline AL539_24-3 & $07: 57$ & Fish Net & 10.07. & $55^{\circ} 43,325^{\prime} \mathrm{N}$ & $016^{\circ} 15,609^{\prime} \mathrm{E}$ & 63 \\
\hline AL539_25-1 & $10: 46$ & CTD & 10.07. & $55^{\circ} 28,252^{\prime} \mathrm{N}$ & $016^{\circ} 15,186^{\prime} \mathrm{E}$ & 72 \\
\hline AL539_25-2 & $10: 58$ & Fish Net & 10.07. & $55^{\circ} 28,339^{\prime} \mathrm{N}$ & $016^{\circ} 15,174^{\prime} \mathrm{E}$ & 72 \\
\hline AL539_26-1 & $13: 15$ & CTD & 10.07. & $55^{\circ} 24,155^{\prime} \mathrm{N}$ & $016^{\circ} 02,429^{\prime} \mathrm{E}$ & 83 \\
\hline AL539_26-2 & $13: 22$ & Fish Net & 10.07. & $55^{\circ} 24,170^{\prime} \mathrm{N}$ & $016^{\circ} 02,488^{\prime} \mathrm{E}$ & 83 \\
\hline AL539_27-1 & $05: 43$ & CTD & 11.07. & $54^{\circ} 57,650^{\prime} \mathrm{N}$ & $015^{\circ} 14,743^{\prime} \mathrm{E}$ & 40 \\
\hline AL539_27-2 & $05: 50$ & \begin{tabular}{|l} 
Niskin Bottle \\
\end{tabular} & 11.07. & $54^{\circ} 57,603^{\prime} \mathrm{N}$ & $015^{\circ} 14,672^{\prime} \mathrm{E}$ & 41 \\
\hline AL539_28-1 & $06: 01$ & CTD & 12.07. & $55^{\circ} 17,567^{\prime} \mathrm{N}$ & $014^{\circ} 59,979^{\prime} \mathrm{E}$ & 70 \\
\hline AL539_28-2 & 06:11 & \begin{tabular}{|l|} 
Niskin Bottle \\
\end{tabular} & 12.07. & $55^{\circ} 17,522^{\prime} \mathrm{N}$ & $014^{\circ} 59,900^{\prime} \mathrm{E}$ & 69 \\
\hline AL539_28-3 & $06: 21$ & Bongo Net & 12.07. & $55^{\circ} 17,479^{\prime} \mathrm{N}$ & $014^{\circ} 59,722^{\prime} \mathrm{E}$ & 69 \\
\hline AL539_29-1 & $08: 10$ & Bongo Net & 12.07. & $55^{\circ} 17,441^{\prime} N$ & $015^{\circ} 16,588^{\prime} \mathrm{E}$ & 83 \\
\hline AL539_29-2 & 08:25 & CTD & 12.07. & $55^{\circ} 17,320^{\prime} \mathrm{N}$ & $015^{\circ} 15,759^{\prime} \mathrm{E}$ & 76 \\
\hline AL539_30-1 & 09:27 & CTD & 12.07. & $55^{\circ} 17,505^{\prime} \mathrm{N}$ & $015^{\circ} 30,057^{\prime} \mathrm{E}$ & 91 \\
\hline AL539_30-2 & 09:37 & Bongo Net & 12.07. & $55^{\circ} 17,486^{\prime} \mathrm{N}$ & $015^{\circ} 29,926^{\prime} \mathrm{E}$ & 91 \\
\hline AL539_31-1 & $11: 23$ & Bongo Net & 12.07. & $55^{\circ} 07,698^{\prime} \mathrm{N}$ & $015^{\circ} 46,423^{\prime} \mathrm{E}$ & 86 \\
\hline AL539_31-2 & $11: 41$ & CTD & 12.07. & $55^{\circ} 07,521^{\prime} \mathrm{N}$ & $015^{\circ} 45,151^{\prime} \mathrm{E}$ & 86 \\
\hline AL539_32-1 & $12: 38$ & CTD & 12.07. & $55^{\circ} 07,378^{\prime} \mathrm{N}$ & $016^{\circ} 00,002^{\prime} \mathrm{E}$ & 84 \\
\hline AL539_32-2 & $12: 47$ & \begin{tabular}{|l|} 
Niskin Bottle \\
\end{tabular} & 12.07. & $55^{\circ} 07,361^{\prime} \mathrm{N}$ & $015^{\circ} 59,943^{\prime} \mathrm{E}$ & 84 \\
\hline AL539_32-3 & $12: 53$ & Bongo Net & 12.07. & $55^{\circ} 07,339^{\prime} \mathrm{N}$ & $015^{\circ} 59,902^{\prime} \mathrm{E}$ & 85 \\
\hline AL539_33-1 & $14: 17$ & Bongo Net & 12.07. & $54^{\circ} 57,612^{\prime} \mathrm{N}$ & $016^{\circ} 01,024^{\prime} \mathrm{E}$ & 70 \\
\hline AL539_33-2 & $14: 30$ & CTD & 12.07. & $54^{\circ} 57,465^{\prime} \mathrm{N}$ & $016^{\circ} 00,282^{\prime} \mathrm{E}$ & 71 \\
\hline AL539_34-1 & $15: 37$ & CTD & 12.07. & $54^{\circ} 57,485^{\prime} \mathrm{N}$ & $015^{\circ} 45,064^{\prime} \mathrm{E}$ & 78 \\
\hline AL539_34-2 & $15: 45$ & Bongo Net & 12.07. & $54^{\circ} 57,454^{\prime} \mathrm{N}$ & $015^{\circ} 44,984^{\prime} \mathrm{E}$ & 79 \\
\hline AL539_35-1 & $16: 49$ & Bongo Net & 12.07. & $54^{\circ} 57,638^{\prime} \mathrm{N}$ & $015^{\circ} 31,207^{\prime} \mathrm{E}$ & 74 \\
\hline AL539_35-2 & $17: 04$ & CTD & 12.07. & $54^{\circ} 57,514^{\prime} \mathrm{N}$ & $015^{\circ} 30,070^{\prime} \mathrm{E}$ & 74 \\
\hline AL539_36-1 & $18: 12$ & CTD & 12.07. & $54^{\circ} 57,478^{\prime} \mathrm{N}$ & $015^{\circ} 15,055^{\prime} \mathrm{E}$ & 40 \\
\hline AL539_36-2 & $18: 22$ & Bongo Net & 12.07. & $54^{\circ} 57,440^{\prime} \mathrm{N}$ & $015^{\circ} 14,881^{\prime} \mathrm{E}$ & 40 \\
\hline AL539_37-1 & $19: 48$ & Bongo Net & 12.07. & $55^{\circ} 07,558^{\prime} \mathrm{N}$ & $015^{\circ} 31,148^{\prime} \mathrm{E}$ & 66 \\
\hline AL539_37-2 & 20:06 & CTD & 12.07. & $55^{\circ} 07,528^{\prime} \mathrm{N}$ & $015^{\circ} 29,853^{\prime} \mathrm{E}$ & 65 \\
\hline AL539_38-1 & $21: 06$ & CTD & 12.07. & $55^{\circ} 07,490^{\prime} \mathrm{N}$ & $015^{\circ} 15,125^{\prime} \mathrm{E}$ & 59 \\
\hline AL539_38-2 & $21: 15$ & Bongo Net & 12.07. & $55^{\circ} 07,451^{\prime} \mathrm{N}$ & $015^{\circ} 14,988^{\prime} \mathrm{E}$ & 59 \\
\hline AL539_39-1 & 06:07 & Bongo Net & 13.07. & $55^{\circ} 17,382^{\prime} \mathrm{N}$ & $015^{\circ} 46,833^{\prime} \mathrm{E}$ & 93 \\
\hline AL539_39-2 & $06: 29$ & CTD & 13.07. & $55^{\circ} 17,495^{\prime} \mathrm{N}$ & $015^{\circ} 44,998^{\prime} \mathrm{E}$ & 94 \\
\hline AL539_40-1 & $07: 30$ & CTD & 13.07. & $55^{\circ} 17,480^{\prime} \mathrm{N}$ & $016^{\circ} 00,033^{\prime} \mathrm{E}$ & 88 \\
\hline AL539_40-2 & $07: 41$ & Bongo Net & 13.07. & $55^{\circ} 17,464^{\prime} N$ & $015^{\circ} 59,903^{\prime} \mathrm{E}$ & 87 \\
\hline AL539_41-1 & $08: 53$ & Bongo Net & 13.07. & $55^{\circ} 17,424^{\prime} \mathrm{N}$ & $016^{\circ} 16,012^{\prime} \mathrm{E}$ & 70 \\
\hline AL539_41-2 & 09:08 & CTD & 13.07. & $55^{\circ} 17,470^{\prime} \mathrm{N}$ & $016^{\circ} 15,079^{\prime} \mathrm{E}$ & 72 \\
\hline AL539_42-1 & $10: 41$ & CTD & 13.07. & $55^{\circ} 27,493^{\prime} \mathrm{N}$ & $016^{\circ} 00,166^{\prime} \mathrm{E}$ & 81 \\
\hline AL539_42-2 & $10: 52$ & Niskin Bottle & 13.07. & $55^{\circ} 27,474^{\prime} N$ & $016^{\circ} 00,079^{\prime} \mathrm{E}$ & 81 \\
\hline
\end{tabular}




\begin{tabular}{|c|c|c|c|c|c|c|}
\hline AL539_42-3 & $10: 58$ & Bongo Net & 13.07. & $55^{\circ} 27,462^{\prime} \mathrm{N}$ & $015^{\circ}$ 59,953' E & 82 \\
\hline AL539_43-1 & $11: 57$ & Bongo Net & 13.07. & $55^{\circ} 27,546^{\prime} \mathrm{N}$ & $015^{\circ} 46,169^{\prime} \mathrm{E}$ & 84 \\
\hline AL539_43-2 & $12: 12$ & CTD & 13.07. & $55^{\circ} 27,491^{\prime} \mathrm{N}$ & $015^{\circ} 45,033^{\prime} \mathrm{E}$ & 83 \\
\hline AL539_44-1 & $13: 11$ & CTD & 13.07. & $55^{\circ} 27,509^{\prime} \mathrm{N}$ & $015^{\circ} 30,050^{\prime} \mathrm{E}$ & 83 \\
\hline AL539_44-2 & $13: 21$ & Bongo Net & 13.07. & $55^{\circ} 27,474^{\prime} \mathrm{N}$ & $015^{\circ} 29,913^{\prime} \mathrm{E}$ & 83 \\
\hline AL539_45-1 & $14: 17$ & Bongo Net & 13.07. & $55^{\circ} 27,426^{\prime} \mathrm{N}$ & $015^{\circ} 16,004^{\prime} \mathrm{E}$ & 87 \\
\hline AL539_45-2 & $14: 32$ & CTD & 13.07. & $55^{\circ} 27,467^{\prime} \mathrm{N}$ & $015^{\circ} 15,016^{\prime} \mathrm{E}$ & 88 \\
\hline AL539_46-1 & $15: 30$ & CTD & 13.07. & $55^{\circ} 27,495^{\prime} \mathrm{N}$ & $015^{\circ} 00,071^{\prime} \mathrm{E}$ & 76 \\
\hline AL539_46-2 & $15: 39$ & Bongo Net & 13.07. & $55^{\circ} 27,431^{\prime} \mathrm{N}$ & $014^{\circ} 59,962^{\prime} \mathrm{E}$ & 75 \\
\hline AL539_47-1 & $16: 33$ & Bongo Net & 13.07. & $55^{\circ} 27,639^{\prime} \mathrm{N}$ & $014^{\circ} 46,124^{\prime} \mathrm{E}$ & 67 \\
\hline AL539_47-2 & $16: 49$ & CTD & 13.07. & $55^{\circ} 27,500^{\prime} \mathrm{N}$ & $014^{\circ} 45,023^{\prime} \mathrm{E}$ & 67 \\
\hline AL539_48-1 & $17: 57$ & CTD & 13.07. & $55^{\circ} 37,465^{\prime} \mathrm{N}$ & $014^{\circ} 44,920^{\prime} \mathrm{E}$ & 66 \\
\hline AL539_48-2 & 18:06 & Bongo Net & 13.07. & $55^{\circ} 37,525^{\prime} \mathrm{N}$ & $014^{\circ} 44,788^{\prime} \mathrm{E}$ & 65 \\
\hline AL539_49-1 & 19:12 & Bongo Net & 13.07. & $55^{\circ} 36,838^{\prime} \mathrm{N}$ & $015^{\circ} 00,609^{\prime} \mathrm{E}$ & 74 \\
\hline AL539_49-2 & 19:28 & CTD & 13.07. & $55^{\circ} 37,487^{\prime} \mathrm{N}$ & $014^{\circ} 59,982^{\prime} \mathrm{E}$ & 74 \\
\hline AL539_50-1 & $20: 26$ & CTD & 13.07. & $55^{\circ} 37,503^{\prime} \mathrm{N}$ & $015^{\circ} 15,042^{\prime} \mathrm{E}$ & 70 \\
\hline AL539_50-2 & $20: 36$ & \begin{tabular}{|l|} 
Niskin Bottle \\
\end{tabular} & 13.07. & $55^{\circ} 37,501^{\prime} \mathrm{N}$ & $015^{\circ} 15,022^{\prime} \mathrm{E}$ & 70 \\
\hline AL539_50-3 & $20: 41$ & Bongo Net & 13.07. & $55^{\circ} 37,484^{\prime} \mathrm{N}$ & $015^{\circ} 14,962^{\prime} \mathrm{E}$ & 70 \\
\hline AL539_51-1 & 06:01 & Bongo Net & 14.07. & $55^{\circ} 37,813^{\prime} \mathrm{N}$ & $015^{\circ} 30,640^{\prime} \mathrm{E}$ & 65 \\
\hline AL539_51-2 & 06:15 & CTD & 14.07. & $55^{\circ} 37,516^{\prime} \mathrm{N}$ & $015^{\circ} 30,014^{\prime} \mathrm{E}$ & 65 \\
\hline AL539_52-1 & $07: 10$ & CTD & 14.07. & $55^{\circ} 37,495^{\prime} \mathrm{N}$ & $015^{\circ} 45,042^{\prime} \mathrm{E}$ & 67 \\
\hline AL539_52-2 & $07: 20$ & Bongo Net & 14.07. & $55^{\circ} 37,430^{\prime} \mathrm{N}$ & $015^{\circ} 44,999^{\prime} \mathrm{E}$ & 67 \\
\hline AL539_53-1 & 08:17 & Bongo Net & 14.07. & $55^{\circ} 37,351^{\prime} \mathrm{N}$ & $015^{\circ} 59,223^{\prime} \mathrm{E}$ & 73 \\
\hline AL539_53-2 & $08: 32$ & CTD & 14.07. & $55^{\circ} 37,515^{\prime} \mathrm{N}$ & $015^{\circ} 59,964^{\prime} \mathrm{E}$ & 72 \\
\hline AL539_54-1 & 09:33 & CTD & 14.07. & $55^{\circ} 47,504^{\prime} \mathrm{N}$ & $016^{\circ} 00,082^{\prime} E$ & 59 \\
\hline AL539_54-2 & 09:42 & Bongo Net & 14.07. & $55^{\circ} 47,545^{\prime} \mathrm{N}$ & $016^{\circ} 00,066^{\prime} \mathrm{E}$ & 59 \\
\hline AL539_55-1 & $10: 37$ & Bongo Net & 14.07. & $55^{\circ} 47,505^{\prime} \mathrm{N}$ & $016^{\circ} 14,275^{\prime} \mathrm{E}$ & 57 \\
\hline AL539_55-2 & $10: 48$ & CTD & 14.07. & $55^{\circ} 47,487^{\prime} \mathrm{N}$ & $016^{\circ} 15,059^{\prime} \mathrm{E}$ & 57 \\
\hline AL539_56-1 & $11: 45$ & CTD & 14.07. & $55^{\circ} 47,495^{\prime} \mathrm{N}$ & $016^{\circ} 30,018^{\prime} \mathrm{E}$ & 53 \\
\hline AL539_56-2 & $11: 53$ & Bongo Net & 14.07. & $55^{\circ} 47,417^{\prime} \mathrm{N}$ & $016^{\circ} 30,081^{\prime} \mathrm{E}$ & 54 \\
\hline AL539_57-1 & $12: 51$ & Bongo Net & 14.07. & $55^{\circ} 37,873^{\prime} \mathrm{N}$ & $016^{\circ} 29,550^{\prime} \mathrm{E}$ & 56 \\
\hline AL539_57-2 & $13: 02$ & CTD & 14.07. & $55^{\circ} 37,575^{\prime} \mathrm{N}$ & $016^{\circ} 29,866^{\prime} \mathrm{E}$ & 60 \\
\hline AL539_58-1 & $13: 56$ & CTD & 14.07. & $55^{\circ} 37,497^{\prime} \mathrm{N}$ & $016^{\circ} 14,957^{\prime} \mathrm{E}$ & 72 \\
\hline AL539_58-2 & $14: 04$ & Bongo Net & 14.07. & $55^{\circ} 37,465^{\prime} \mathrm{N}$ & $016^{\circ} 15,038^{\prime} \mathrm{E}$ & 73 \\
\hline AL539_59-1 & $15: 08$ & Bongo Net & 14.07. & $55^{\circ} 27,724^{\prime} \mathrm{N}$ & $016^{\circ} 14,189^{\prime} \mathrm{E}$ & 72 \\
\hline AL539_59-2 & $15: 21$ & CTD & 14.07. & $55^{\circ} 27,541^{\prime} \mathrm{N}$ & $016^{\circ} 14,944^{\prime} \mathrm{E}$ & 72 \\
\hline AL539_60-1 & $16: 20$ & CTD & 14.07. & $55^{\circ} 27,511^{\prime} \mathrm{N}$ & $016^{\circ} 29,966^{\prime} \mathrm{E}$ & 55 \\
\hline AL539_60-2 & $16: 28$ & Bongo Net & 14.07. & $55^{\circ} 27,519^{\prime} \mathrm{N}$ & $016^{\circ} 30,047^{\prime} \mathrm{E}$ & 55 \\
\hline AL539_61-1 & $17: 35$ & Bongo Net & 14.07. & $55^{\circ} 17,621^{\prime} \mathrm{N}$ & $016^{\circ} 29,261^{\prime} \mathrm{E}$ & 58 \\
\hline AL539_61-2 & $17: 49$ & CTD & 14.07. & $55^{\circ} 17,514^{\prime} \mathrm{N}$ & $016^{\circ} 30,072^{\prime} \mathrm{E}$ & 59 \\
\hline AL539_62-1 & $18: 56$ & CTD & 14.07. & $55^{\circ} 07,489^{\prime} \mathrm{N}$ & $016^{\circ} 29,933^{\prime} \mathrm{E}$ & 48 \\
\hline AL539_62-2 & 19:04 & Bongo Net & 14.07. & $55^{\circ} 07,495^{\prime} \mathrm{N}$ & $016^{\circ} 30,140^{\prime} \mathrm{E}$ & 48 \\
\hline AL539_63-1 & $20: 09$ & Bongo Net & 14.07. & $55^{\circ} 07,647^{\prime} \mathrm{N}$ & $016^{\circ} 13,749^{\prime} \mathrm{E}$ & 79 \\
\hline AL539_63-2 & $20: 27$ & CTD & 14.07. & $55^{\circ} 07,493^{\prime} \mathrm{N}$ & $016^{\circ} 14,956^{\prime} \mathrm{E}$ & 78 \\
\hline AL539_64-1 & $21: 35$ & CTD & 14.07. & $54^{\circ} 57,524^{\prime} \mathrm{N}$ & $016^{\circ} 14,970^{\prime} \mathrm{E}$ & 47 \\
\hline AL539_64-2 & $21: 44$ & Bongo Net & 14.07. & $54^{\circ} 57,526^{\prime} \mathrm{N}$ & $016^{\circ} 15,103^{\prime} \mathrm{E}$ & 47 \\
\hline AL539_65-1 & 06:01 & CTD & 15.07. & $54^{\circ} 37,478^{\prime} \mathrm{N}$ & $015^{\circ} 45,018^{\prime} \mathrm{E}$ & 57 \\
\hline AL539_65-2 & 06:10 & Niskin Bottle & 15.07. & $54^{\circ} 37,447^{\prime} \mathrm{N}$ & $015^{\circ} 45,005^{\prime} \mathrm{E}$ & 57 \\
\hline AL539_65-3 & $06: 15$ & Bongo Net & 15.07. & $54^{\circ} 37,442^{\prime} \mathrm{N}$ & $015^{\circ} 44,958^{\prime} \mathrm{E}$ & 57 \\
\hline AL539_66-1 & 07:11 & Bongo Net & 15.07. & $54^{\circ} 37,415^{\prime} \mathrm{N}$ & $015^{\circ} 30,609^{\prime} \mathrm{E}$ & 61 \\
\hline
\end{tabular}




\begin{tabular}{|c|c|c|c|c|c|c|}
\hline AL539_66-2 & $07: 22$ & CTD & 15.07. & $54^{\circ} 37,493^{\prime} \mathrm{N}$ & $015^{\circ} 29,961^{\prime} \mathrm{E}$ & 61 \\
\hline AL539 67-1 & $08: 17$ & CTD & 15.07. & $54^{\circ} 37,463^{\prime} \mathrm{N}$ & $015^{\circ} 14,983^{\prime} \mathrm{E}$ & 56 \\
\hline AL539_67-2 & $08: 25$ & Bongo Net & 15.07. & $54^{\circ} 37,453^{\prime} \mathrm{N}$ & $015^{\circ} 14,799^{\prime} \mathrm{E}$ & 56 \\
\hline AL539_68-1 & 09:39 & Bongo Net & 15.07. & $54^{\circ} 47,343^{\prime} \mathrm{N}$ & $015^{\circ} 00,835^{\prime} \mathrm{E}$ & 58 \\
\hline AL539_68-2 & $09: 52$ & CTD & 15.07. & $54^{\circ} 47,469^{\prime} \mathrm{N}$ & $015^{\circ} 00,003^{\prime} \mathrm{E}$ & 57 \\
\hline AL539_69-1 & $10: 55$ & CTD & 15.07. & $54^{\circ} 47,522^{\prime} \mathrm{N}$ & $015^{\circ} 15,115^{\prime} \mathrm{E}$ & 65 \\
\hline AL539_69-2 & $11: 04$ & Bongo Net & 15.07. & $54^{\circ} 47,549^{\prime} \mathrm{N}$ & $015^{\circ} 14,917^{\prime} \mathrm{E}$ & 65 \\
\hline AL539_70-1 & $12: 00$ & Bongo Net & 15.07. & $54^{\circ} 47,342^{\prime} \mathrm{N}$ & $015^{\circ} 29,111^{\prime} \mathrm{E}$ & 71 \\
\hline AL539_70-2 & $12: 14$ & CTD & 15.07. & $54^{\circ} 47,495^{\prime} \mathrm{N}$ & $015^{\circ} 29,965^{\prime} \mathrm{E}$ & 71 \\
\hline AL539_71-1 & $13: 09$ & CTD & 15.07. & $54^{\circ} 47,414^{\prime} \mathrm{N}$ & $015^{\circ} 45,000^{\prime} \mathrm{E}$ & 69 \\
\hline AL539_71-2 & $13: 18$ & Bongo Net & 15.07. & $54^{\circ} 47,437^{\prime} \mathrm{N}$ & $015^{\circ} 44,934^{\prime} \mathrm{E}$ & 69 \\
\hline AL539_72-1 & $14: 13$ & Bongo Net & 15.07. & $54^{\circ} 47,314^{\prime} \mathrm{N}$ & $015^{\circ} 59,275^{\prime} \mathrm{E}$ & 49 \\
\hline AL539_72-2 & $14: 24$ & CTD & 15.07. & $54^{\circ} 47,517^{\prime} \mathrm{N}$ & $015^{\circ} 59,940^{\prime} \mathrm{E}$ & 48 \\
\hline AL539_73-1 & 06:48 & CTD & 16.07. & $55^{\circ} 27,066^{\prime} \mathrm{N}$ & $014^{\circ} 47,572^{\prime} \mathrm{E}$ & 68 \\
\hline AL539_73-2 & $06: 58$ & Fish Net & 16.07. & $55^{\circ} 27,044^{\prime} \mathrm{N}$ & $014^{\circ} 47,539^{\prime} \mathrm{E}$ & 68 \\
\hline AL539_73-3 & 08:09 & Bongo Net & 16.07. & $55^{\circ} 27,585^{\prime} \mathrm{N}$ & $014^{\circ} 43,207^{\prime} \mathrm{E}$ & 67 \\
\hline AL539_74-1 & 09:29 & CTD & 16.07. & $55^{\circ} 22,286^{\prime} \mathrm{N}$ & $014^{\circ} 52,133^{\prime} \mathrm{E}$ & 66 \\
\hline AL539_74-2 & 09:36 & \begin{tabular}{|l|} 
Fish Net \\
\end{tabular} & 16.07. & $55^{\circ} 22,301^{\prime} \mathrm{N}$ & $014^{\circ} 52,055^{\prime} \mathrm{E}$ & 66 \\
\hline AL539_75-1 & $13: 01$ & CTD & 16.07. & $55^{\circ} 21,347^{\prime} \mathrm{N}$ & $015^{\circ} 29,590^{\prime} \mathrm{E}$ & 92 \\
\hline AL539_75-2 & $13: 10$ & Fish Net & 16.07. & $55^{\circ} 21,392^{\prime} \mathrm{N}$ & $015^{\circ} 29,442^{\prime} \mathrm{E}$ & 92 \\
\hline AL539_76-1 & $05: 54$ & CTD & 17.07. & $55^{\circ} 19,058^{\prime} \mathrm{N}$ & $016^{\circ} 43,543^{\prime} \mathrm{E}$ & 66 \\
\hline AL539_76-2 & $06: 06$ & Fish Net & 17.07. & $55^{\circ} 19,130^{\prime} \mathrm{N}$ & $016^{\circ} 43,631^{\prime} \mathrm{E}$ & 66 \\
\hline AL539_77-1 & 09:50 & CTD & 17.07. & $55^{\circ} 04,165^{\prime} \mathrm{N}$ & $016^{\circ} 20,097^{\prime} \mathrm{E}$ & 63 \\
\hline AL539_77-2 & 09:57 & Fish Net & 17.07. & $55^{\circ} 04,198^{\prime} \mathrm{N}$ & $016^{\circ} 20,101^{\prime} \mathrm{E}$ & 63 \\
\hline AL539_78-1 & 05:46 & CTD & 18.07. & $54^{\circ} 13,774^{\prime} \mathrm{N}$ & $011^{\circ} 52,905^{\prime} \mathrm{E}$ & 16 \\
\hline AL539_78-2 & $05: 53$ & Fish Net & 18.07. & $54^{\circ} 13,647^{\prime} \mathrm{N}$ & $011^{\circ} 52,895^{\prime} \mathrm{E}$ & 16 \\
\hline
\end{tabular}

\section{$7 \quad$ Data and Sample Storage and Availability}

\subsection{Data availability}

a) The station list meta data (time, position, gear) will be transferred to the DOD.

b) CTD data will be quality checked and transferred into PANGAEA.

c) A cruise summary report (CSR) will be send by the cruise leader to the $\mathrm{BSH}$.

d) The cruise leader confirms the data transfer from a) and b) in his cruise report.

e) The cruise leader will supply detailed information about the analysis of samples and long term storage of the data and samples in his cruise report. Diplomatic mandatory data transfers to visited states will be conducted by the cruise leader.

\subsection{Sample availability and storage}

a) Samples will be analysed within the IMF teaching modules and student thesis's and stored within the IMF.

b) IMF has its own cruise data base and a certified storage for formalin samples. Frozen samples will be stored in $-20^{\circ} \mathrm{C},-40^{\circ} \mathrm{C}$, or $-80^{\circ} \mathrm{C}$ containers at the IMF, which are equipped with an automatic, mobile phone based, alarm system.

c) Samples will be labelled including a barcoding scheme, which is also used for professional archiving of all samples (long-term storage via an external company). 


\section{3}

\section{Data storage}

a) Tentative scientific data from this cruise will be

a. CTD data, light measurements, fluorescence data

b. Hydroacoustic data (EK 60 \& EK 80; 38, 70, 120, 200, $333 \mathrm{kHz}$ )

c. Fisheries data

d. Zooplankton data from net samples

b) Paper protocols will be entered in a database continuously during the entire cruise (including daily back up) and conserved as hard copies as well.

c) After quality checks and after their use in publications, data will be submitted to the PANGEA database. The data transfer will be done within three years. Before transfer the data will be stored within the IMF data storage server system (RAID 5 $\&$ tape libraries).

\section{Acknowledgements}

I want to thank the captain Jan Lass and the entire crew of RV ALKOR for their outstanding support throughout the cruise, Svend Mees (GEOMAR) for his support with technical equipment for the cruise and Margarethe Nowicki for the great collaboration on cruise preparations and follow-up work during the cruise. A special thanks goes to Dr. Luisa Listmann for her tireless effort during the creation of the online teaching module. Finally, many thanks go to the scientific cruise participants on AL539 for their enthusiasm and motivation throughout the cruise.

\section{References}

Lambert, Yvan, and J-D. Dutil, 1997. Condition and energy reserves of Atlantic cod (Gadus morhua) during the collapse of the northern Gulf of St. Lawrence stock. In: Canadian journal of fisheries and aquatic sciences 54.10: 2388-2400.

\section{Abbreviations}

CTD Conductivity Temperature Depth probe

WS Water Sampler (Niskin Bottle)

Bongo Plankton Net

MSN Multi opening/closing net (MultiNet)

FishNet Youngfishtrawl (for pelagic and bottom near use) with a trawl-eye 